Portland State University

PDXScholar

Fall 1-7-2016

\title{
A Bridge Across the Pacific: A Study of the Shifting Relationship Between Portland and the Far East
}

Michael Todd Gagle

Portland State University

Follow this and additional works at: https://pdxscholar.library.pdx.edu/open_access_etds

Part of the Chinese Studies Commons, Japanese Studies Commons, and the United States History Commons

Let us know how access to this document benefits you.

\section{Recommended Citation}

Gagle, Michael Todd, "A Bridge Across the Pacific: A Study of the Shifting Relationship Between Portland and the Far East" (2016). Dissertations and Theses. Paper 2655.

https://doi.org/10.15760/etd.2651

This Thesis is brought to you for free and open access. It has been accepted for inclusion in Dissertations and Theses by an authorized administrator of PDXScholar. Please contact us if we can make this document more accessible: pdxscholar@pdx.edu. 


\section{A Bridge Across the Pacific}

A Study of the Shifting Relationship Between Portland and the Far East in the 1930s

by

Michael Todd Gagle

A thesis submitted in partial fulfillment of the

requirements for the degree of

\section{Master of Arts}

in

History

Thesis Committee:

Kenneth Ruoff, Chair

Desmond Cheung

David Johnson

Jon Holt

Portland State University

2015 
(C) 2015 Michael Todd Gagle 


\begin{abstract}
After Japan invaded Manchuria in 1931, both Japan and China sought the support of America. There has been a historical assumption that, starting with the hostilities in 1931, the Japanese were maligned in American public opinion. Consequently, the assumption has been made that Americans supported the Chinese without reserve during their conflict with Japan in the 1930 s.
\end{abstract}

The aim of this study is to question the accuracy of that assumption in the case of Portland, Oregon. An analysis of newspapers and print material specifically focusing on Japan and China from before the conflict reveal that the general American opinion of Japan by 1931 had shifted from admiration to suspicion and fear. The American view of China, meanwhile, had shifted from contempt to pity. When Japan invaded China, both countries lobbied for support via books, articles, and public speakers. By analyzing the speeches and publications available, this study finds that the Japanese argued for security and economic benefit, while the Chinese argued for liberty and justice.

In Portland, the public opinion was strongly supportive of Japan before the 1930s, and Japan's hostilities toward China did not immediately change the opinion. Instead, an analysis of The Oregonian, the Portland City Club, and a student summit at Reed college reveal that the opinion in Portland was far more forgiving of Japan than the general American outlook. Portlanders focused on how to ease the tensions between Japan and America, even supporting Japanese calls for an Asian League of Nations headed by Japan. 
Further complicating the discourse in Portland was the issue of communism. Portland - and the Pacific Northwest in general - had been very involved with socialism in the period before the First World War. After the war, support for socialism had diverged into support for communism, for those who remained radicals, and vehement distrust of communism, for those who did not. The tension between these two groups led to outbursts of violence that left a mark on the memories of the people of the Northwest. Those who supported communism remembered the slights, which would lead them to support the Bolsheviks in the 1930s. Those who distrusted communism remembered the real threat that communism represented.

When the Japanese began their propaganda against China, one of their strongest claims was that the Chinese could not hold back the tide of communism, and that only Japan was properly prepared to do so in East Asia. This claim brought up old fears in the Portland populace, most of whom did not support communism. Thus, Japanese claims of working to prevent the communist threat, coupled with the assertion of an economic boon, helped maintain a more favorable view of Japan in Portland. Following the 1937 attack on Nanking, however, Japanese action was deemed reprehensible and Portland began to turn against Japan.

By profiling the public opinion of Portland toward Japan in the 1930s, this study adds to the growing body of research on the complexities of the relationship between America and Japan during the twentieth century. 


\section{Table of Contents}

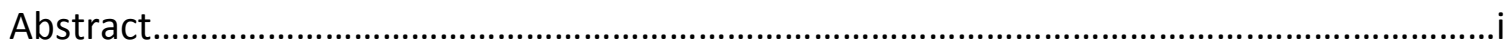

Introduction

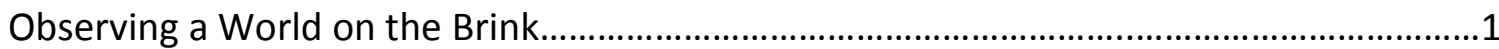

Chapter One

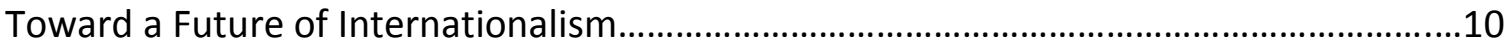

Chapter Two

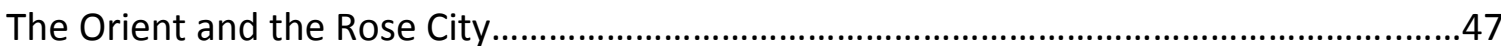

Chapter Three

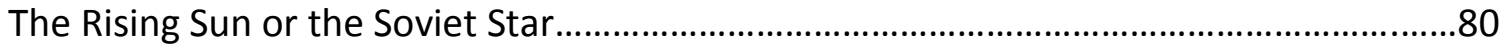

Conclusion

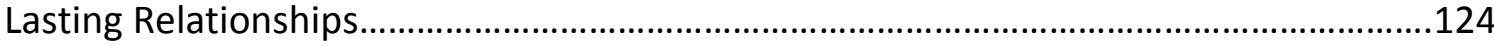

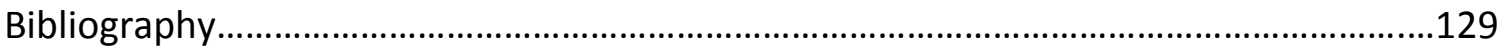




\section{Observing a World on the Brink}

On September eighteenth, 1931, the world changed. A small explosion manufactured by Japanese forces in Mukden, in northeastern China, became the first domino to fall in what became the bloodiest war in human history. Dissatisfied with the limitations placed on Japanese growth in the international society, a semi-rogue branch of the Japanese military planned and executed the attack, which would draw a divided Japan into a war for the future of the empire. In an already tense world, this attack, dubbed the Manchurian Incident or the Mukden Incident, sent shockwaves across the globe. Suddenly, all eyes were on China. What began as a series of skirmishes that most assumed would be swiftly resolved - tensions had flared between Japan and China intermittently since the First Sino-Japanese War in 1895 - turned into a six-year-long series of "incidents" and the creation of a new state in northeast China, Manchukuo, ${ }^{1}$ before war was officially declared in 1937.

Although historians now identify the fighting from 1931 onward as part of the Second Sino-Japanese War, the classification was debated at the time. Chinese supporters termed the Japanese aggression as an "undeclared war" aimed at conquering China. Meanwhile, Japanese supporters pushed the narrative that the fighting was merely a series of incidents that indicated a desire for local independence from China. Complicating the issue was the strained internationalism represented by the League of Nations. The new standard bearer for international cooperation after The

\footnotetext{
${ }^{1}$ Also known as Manchoukuo and Manzhouguo.
} 
Great War, the League of Nations represented a desire to keep the peace by means of maintaining the status quo - which neither Japan nor China were content with. Japan had found themselves up against the glass ceiling of their "honorary whiteness" in the international society, and desired a greater ability to create an empire. China was unhappy because the status quo which the League of Nations sought to maintain was one where China remained weak and exploited.

These components blended to make an unprecedented situation, what was contemporarily labeled the Far East problem. The recently established international mentality led to many countries supporting a return to the status quo which pleased neither Japan nor China, while both combatants lobbied for support on their own platforms. Since Japan knew it would not be allowed to maintain its international standing while fighting a rogue war, and China needed the assistance, both countries sought the favor of the rest of the world. Japan and China both coveted American favor due to America's neutrality, position in the international society, and value as a trade partner - especially during wartime.

The calls for American aid and allegiance were both prevalent and loud. While Britain's pleas for aid in the war against Germany starting in 1939 still resound in American popular memory via political cartoons and politicians' rhetoric, and images of Nazi flags flying next to the stars and stripes still stir up thoughts of the GermanAmerican Bund, Americans often forget the amount of propaganda that came from the 
East. $^{2}$ Both China and Japan vied for American support throughout the 1930 s. Unlike German and British pleas that relied upon shared lineage or culture, Japan and China had to state their cases as outsiders. The logical place to start this effort in the U.S. was the cities in which Japan and China had established relationships, such as the West Coast port cities of San Francisco, Seattle, and Portland.

\section{Portland, Oregon}

This study will focus on the efforts of China and Japan to sway the smallest of the West Coast population centers: Portland, Oregon.

Why Portland? Outside of its location, Portland was unique amongst West Coast population centers in that there were connections and historical relations with both China and Japan, including heavy immigration from both countries during the late nineteenth and early twentieth century. However, by the 1930 s there was no longer a substantial immigrant population from either Japan or China. Unlike San Francisco or Seattle, where the ratio heavily favored Chinese immigrants, Portland did not have a substantial immigrant community of either group that could sway opinions. Although there were certainly important connections with both China and Japan in the personal and business realms, there was no ingrained bias toward either side. Second, Portland was a city of mostly business-people and laborers, neither of whom were particularly internationally-minded. Portland was small and isolated enough that it was even

\footnotetext{
2 'Popular Memory,' as used here, is the combination of general American education (through high school), popular entertainment (books, movies, etc.), and works of popular history.
} 
disconnected from the rest of the United States in some regards, as evidenced by the popularity of heterodox political parties in the Northwest during the first two decades of the century. While not quite the wild frontier any longer, Portland still held on to aspects of that independent identity well into the 1930s. All of these factors made Portland an appealing location to analyze the propaganda from the East and the discourse it inspired.

The aim of this study is to analyze the discourse in Portland about the rising tensions and future of the Far East. First, I will examine nation-wide publications discussing Japan and China from the 1895 Sino-Japanese War onward. The purpose of this review is to ascertain the national opinion toward the Japanese and Chinese nations up through the 1930s. The insight gained will provide a standard against which the discussion in Portland can be measured. Next will be a discussion of the historical interaction between Portland and both China and Japan, leading into a discussion of the fighting in China in the 1930s. To analyze this discussion there will be a breakdown of the various means of discourse in Portland at the time, from newspaper articles to speakers and conferences on the subject. Finally, the last chapter features a discussion on developments unique to Portland and the Northwest which could have influenced opinions. Specifically, this chapter will discuss the evolution of labor and other heterodox political movements in the Northwest, and how the lingering memories of these parties influenced the discourse in Portland. 
The goal of this study is to refute the assumption that the United States saw through Japanese claims and supported China without reserve leading up to World War II. By analyzing the discourse in Portland, I argue that the discussion was far more nuanced and less one-sided than Americans like to remember. Refuting this assumption will be accomplished through a discussion of the cultural background in Portland and how it influenced the effectiveness of oft-ignored Chinese and Japanese propaganda. By examining the discourse in Portland leading up to and during the conflict in East Asia, this study reconstructs the reaction to the Far East problem in Portland.

Quantifying public opinion is a difficult task. Public opinion is nebulous at the best of times, so measuring it is often as much about making inferences as it is about actual data. To address this difficulty, this study attempts to gain the most accurate measurement of opinion by utilizing popular publications like newspapers and newsletters. These publications provide an idea of the mainstream center of thought. By analyzing the largest newspaper in the Pacific Northwest and publications from prominent private and public organizations, I have worked to give the most accurate representation of the public opinion possible.

\section{A Historical Assumption}

Studies focusing on the immediate period before the Second Sino-Japanese War in Japan often frame their discussion in the eventuality of war. It seems that one cannot discuss the immediate pre-war period without addressing the "what went wrong" question. However, constructs such as Manchukuo are less subject to the same scrutiny. 
Historian Yamamuro Shin'ichi discusses the question of how to understand Manchukuo deftly in Manchuria under Japanese Dominion. Because there is more denial in Japan surrounding Manchukuo than surrounding the war at large, Yamamuro deemed it necessary to question all assumptions about the puppet state. The Japanese Empire needs to be dissected with the same level of objectivity.

The perceived inevitability of the war has caused historical assumptions, which leave the student of history with only a partial understanding of the conditions surrounding the years leading up to World War II. The general understanding of the American stance on East Asia during the 1930s is that America supported China over Japan. Historian Charles Beard wrote that throughout Japanese aggression in the 1930s, "American sympathy in general had been on the side of China." ${ }^{3}$ Beard also writes that the reason America did not act in Japan was because those rallying for war in America were focused on Germany due to the cultural ties to Europe. While these macro level concepts are technically correct, they disguise the complexities of the American relationship with Japan. By further investigating both Japanese and Chinese attempts to sway American opinions during the 1930s, the accepted assumption that America consistently supported China over Japan proves to be in need of further investigation. This study aims to address the gap in the scholarship by using Portland as an example.

This study focuses largely on propaganda, and it is thus necessary to contextualize it in reference to John Dower's seminal War Without Mercy. Dower's

\footnotetext{
${ }^{3}$ Charles Beard, President Roosevelt and the Coming of War (New Haven: Yale University Press, 1948), 176.
} 
discussion of the role of Japanese and American propaganda during the war is critical to understanding the dehumanization of the enemy during the war. However, Dower's focus is exclusively on propaganda during and after World War II. This study differs by discussing Japanese activity from before the war - especially in regards to empire building through propaganda activities on the international level.

The issue of a larger focal point drawing attention from more complex discussions has hindered the study of Chinese activities in America as well. In the case of China, the distraction is China's struggle to establish an international identity and maintain unity during the 1910s and the 1920s. This era included the 'waking up' of Chinese consciousness to the larger world, and has been the focus of many studies, such as Zhang Yongjin's China in the International System. While these studies are incredibly informative, they focus on China's internal reaction to internationalism more than anything else. On the other side, Akira Iriye has discussed how America and other Western nations were less interested in supporting one nation over another, and more interested in "desperately [seeking] to re-establish a prewar-type international order for trade, investment and other forms of economic transactions." ${ }^{4}$ When combined with the internal struggles that China faced throughout the twentieth century, there has been no shortage of subjects to draw academic attention. This study will focus on the external policies of both the Chinese nationalist and communist supporters, officially sanctioned and otherwise, in America.

\footnotetext{
${ }^{4}$ Akira Iriye, “Japanese Aggression and China's International Position 1931-1949," in The Cambridge History of China Volume 13: Republican China 1912-1949, Part 2, ed. John K. Fairbank et al. (Chicago, University of Chicago Press, 1986), 492.
} 
Finally, credit must also be given to Prasenjit Duara for the concepts given in his work Sovereignty and Authenticity; Manchukuo and the East Asian Modern. Duara's focus on the matter of authenticity to the Japanese is imperative to understanding Japan's method of imperialism. Duara shows that Japan's empire in Manchuria was no mere military takeover, but a planned long-term expansion of the Japanese identity. He shows that Japan's claims of Manchurian independence from China were not just for the benefit of excusing Japanese actions on the international stage, but were an important step to authenticating Japan's expansion to both the Manchurians and the Japanese. Unlike Korea, there was very little direct military control in Manchuria - the Japanese immediately began treating Manchukuo like the country they hoped it would become. Sovereignty and Authenticity shows that while the cynical eye could easily see Japan's motives in Manchukuo, the Japanese government showed every sign of believing their own myth.

\section{Measuring the Tides of Change}

We know so much about how the world changed in 1931. We know the physical means by which it changed, the numbers of lives and dollars that it consumed, and the consequences of the global conflict it led to. What are often overlooked are the machinations surrounding the larger events of the war. The Far East Question was the hot topic in Portland in the 1930s, and the discussion held there shines a light on the efforts of both Japan and China to sway American opinion. Public opinion is often 
difficult to discern, but comprehending it gives us a more nuanced understanding of World War II and the people who fought in it. 


\section{Chapter 1 - Toward a Future of Internationalism}

To many Americans, the Far East was and always had been just that, far away. As preeminent historian Charles Beard notes in President Roosevelt and the Coming of War, "most Americans had little definite knowledge of Far Eastern Affairs. Nor were they, being mainly European in origin, so extensively and deeply enlisted by sympathies or bitterness in the fortunes of [...] Far Eastern countries as in the fortunes of [...] European nations." ${ }^{5}$ Compared to European countries which had colonial interests in Asia, the interests of the United States in the East were mostly limited to the commercial arena. ${ }^{6}$ By the twentieth century, the federal government's stance on East Asia was simply to maintain the status quo codified by the "Open Door" policy, which was that China be, above all else, equally open to trade with the rest of the world. Outside of commercial and diplomatic circles, the interest of the average American in the goings on in East Asia was at best a mild curiosity and at worst indifference. There was an existing concept of how East Asia should be: peaceful toward the West and economically open. How to maintain that relationship was a matter for the diplomats.

However, the support of the American people and government was highly prized in East Asia. The precedent set by the 1905 Treaty of Portsmouth that ended the RussoJapanese War (and won Theodore Roosevelt a Nobel Prize) left America to act as a disinterested peacekeeper in East Asia. Therefore, America's support of one regime over

\footnotetext{
${ }^{5}$ Beard, President Roosevelt and the Coming of War, 176.

${ }^{6}$ While both Guam and the Philippines were ceded to the U.S. in 1899, neither amounted to more than an American base of operations in the South Pacific.
} 
another could be seen as a seal of approval in the international society. America's position was why, since the fall of Qing China in 1912, leaders in both Japan and China worked to gain the support of American diplomats, merchants, and civilians.

For the Japanese, swaying American opinion meant an appeal to American economic interests. The key point of the Japanese argument was that China was insecure and that the Chinese were incapable of correcting the problem. Japanese propaganda argued that stability - even if imposed by military force - was the best solution to insecure Chinese markets, and that Japan would act as a modernizing force that opened China even further to global commerce. Finally, in a goal shared with the United States, Japan pledged to act as the front line against Soviet communism.

Meanwhile, China attempted to convince Americans that the Nationalists could indeed maintain the status quo by repelling communism and subduing rebel actions. Beyond holding back communism, Nationalist China even claimed to be actively promoting Christianity. By adapting to international political ideas and Western ideas such as Christianity, China was making the case that they were developing adequately on their own. The Chinese argued that aggressive Japanese imperialism would be detrimental to their budding Westernization. Both groups presented their arguments via speeches, books in English, and community events.

This chapter lays out the American cultural and intellectual discourse regarding Chinese and Japanese sovereignty up to and including the Manchurian Incident. In understanding how Americans would be receptive to Chinese and Japanese arguments 
in the 1930s, a discussion of American intervention in Asian affairs and popular conceptions of East Asia in the decades prior is necessary. Starting with the First SinoJapanese War in 1895, what was the general American opinion of China and Japan? The Chinese Exclusion Act was passed in 1882, and popular opinion toward Chinese laborers had not drastically changed by 1895 . The Chinese still carried the stigma of sojourning laborers who undercut American workers. ${ }^{7}$ Subsequently, from around the turn of the century to the 1924 Immigration Act, the Japanese replaced the Chinese as the focal point of American xenophobia on the West Coast. To finish framing the discussion as it entered the 1930s, there will be a brief overview of the official Western response to the Manchurian Incident. Understanding both popular opinion and the government's stance places the ensuing pleas and discussions in context.

The remainder of the chapter will review and discuss three aspects of the international discourse after the Manchurian Incident: Chinese claims about Manchukuo and the East Asian conflicts, Japanese rebuttals, and American publications focusing directly on these topics. Though many sources presented here are official or semiofficial in nature, many are private in origin. Both Japanese and Chinese nationals from many different sectors came to the defense of their country's sovereignty. In contrast, American publications represented the groups most interested in East Asia: diplomats, defense strategists, economists, and ideologues. By analyzing the messages from each of these groups, we can comprehend the general themes of the discourse in America.

\footnotetext{
${ }^{7}$ SEE Philip Kuhn, Chinese among Others : Emigration in Modern times (State and Society in East Asia, Lanham: Rowman \& Littlefield Publishers, 2008).
} 
The sudden rise in American discussions surrounding East Asian affairs follows the general trend of post-World War I interest in the international society. Fear of upsetting the delicate global order and repeating the unpleasantness of The Great War brought the concern from beyond just diplomats to the wider citizenry. Therefore, it was no surprise that conflicts in Asia and the rise of Soviet Russia became topics of concern for the American public. By analyzing the historical understandings of the area, statements from representatives of both China and Japan, and the popular response in American publications, we will gain an understanding of the general American opinion on the conflict in East Asia in the 1930s. This understanding will then be contrasted against the opinion in Portland.

\section{Part I: The Story So Far}

The years between the First and Second Sino-Japanese wars saw an evolution of American understanding of Japanese and Chinese people, governments, and international roles. As far as the average citizen was concerned, these far away countries were the stuff of travelers, diplomats, and merchants. A history of the first Sino-Japanese War in 1895 introduces the area by saying that "China, Japan and Corea [sic] are a strange trinity to most of us in the western world." ${ }^{8}$ The prevailing understandings of China and Japan as their conflict became the discussion of America (and the rest of the world) in the 1930 s played an important role in both the American reactions and the Asian countries' rhetoric.

\footnotetext{
${ }^{8}$ Trumbull White, The War in the East (Philadelphia: J. H. Moore Company, 1895), 5
} 
Due to technological advancements, the world had been shrinking steadily since the sixteenth century; by the turn of the twentieth century, shipping goods and people halfway around the globe was a matter of days or weeks, not months or years. Consequently, Western understandings of countries like China had become well developed through centuries of trade and cultural interaction. In contrast, Western understandings of Japan had been limited by their own actions; the country had been in a self-induced isolation from 1639 until 1853. Both of these factors heavily influenced the American impression of each country. China's longstanding troubles in the late Qing period were well known, and the shadow of those troubles hung over China well into the twentieth century. Japan, however, had a revolution before the trappings of its antiquated government could weaken its image in the eyes of the world. Thus, Japan was seen as starting from nothing and rapidly advancing, while China was seen as working out of the hole the Qing had put it in.

\section{China}

American understandings of China by the twentieth century were characterized by an odd mix of admiration and pity. Travel writer Trumbull White wrote in 1895 that the Chinese system "has stood the test of time, enduring longer than any other which man has devised during the world's history." ${ }^{9}$ He then used that compliment to explain how introspective and apathetic the Chinese had become, having been too secure for so long. The overwhelming sentiment was that "the intellectual life of China was decidedly

\footnotetext{
${ }^{9}$ White, The War in the East, 137.
} 
static rather than dynamic." ${ }^{10}$ The great empire of scholars which once intimidated Westerners had been surpassed by modern Euro-American countries, and had become anachronistic. No longer afraid of Chinese civilization, Westerners could patronizingly admire the greatness it once held, like that of a vanquished foe.

The sentiment of appreciation for Chinese culture led to the concept of China "waking up," as is evidenced by a 1909 book on the Far East for American audiences: "great, slumbering China, proud, conservative, but supremely conscious of its latent resources, has been waking up." ${ }^{11}$ In contrast to appreciations for Japanese acceptance of Western ways, one would think that China would be criticized for its obstinacy. "While Japan was as wax before Western teaching, China was marble" ${ }^{12}$ wrote journalist and Far East specialist F.A. McKenzie in 1907, describing how China's pride had kept her from adapting to Western methods before the First Sino-Japanese War. McKenzie goes on to explain that we can respect China's pride, for China truly was great. There was no punishment for China coming late to the table. It is possible that the longer exposure to China had given Americans and Western thinkers in general a more appreciative understanding of Chinese culture. Essentially, Western opinion of China had enough time go from disgust to pity.

When China finally underwent revolution the overwhelming opinion was positive. McKenzie stated that "here then we have China in the first stage of a renaissance [...]

\footnotetext{
${ }^{10}$ Harold M. Vinacke, A History of the Far East in Modern Times (New York: F. S. Crofts \& Co., 1928), 447.

${ }^{11}$ Helen Barrett Montgomery, The Empire of the East (Chicago: A.C. McClurg \& Co., 1909), 223.

${ }^{12}$ Frederick A. McKenzie, The Unveiled East (New York: E.P. Dutton \& Co., 1907), 182.
} 
this great nation, with its enormous, unworked resources, with its merchant princes whose wealth and enterprise can compare with the greatest of our own, with its vast supplies of cheap and capable labour, is stepping out of the darkness into the light."13 American opinions of Chinese sovereignty were apologetic, especially compared to earlier ideas of Qing sovereignty. It certainly did not hurt that the xenophobia toward China had subsided after the immigration was restricted in 1882 . The image of a humbled yet resurgent China led to a sympathetic view of the Chinese by the 1930s.

\section{Japan}

Compared to China, concepts of Japanese sovereignty from 1895 and on were much more complex for Americans. First and foremost, Japan was never conquered by the West, militarily or otherwise. Unlike China, there was no precedent for Japanese capitulation to Western terms on anything but a temporary basis. While unequal treaties were a part of Japan's opening in the mid-nineteenth century, the Japanese never had their sovereignty violated in the way the Chinese had during the Opium War. Afterwards, because of the astonishing speed in which Japan modernized, there was a combination of awe, respect, and fear toward the Japanese which fluctuated during the early twentieth century.

The first American impressions of Japan - both public and private - after the victory over China in 1895 were of respect for her progress. White credits Japan's successes to the progressivism that Commodore Perry imparted upon opening the

\footnotetext{
${ }^{13}$ McKenzie, The Unveiled East, 191.
} 
country, and states that "with the constant impression of western civilization upon them, it is to be hoped that the Japanese will acquire a firm moral and intellectual basis for the manners of life that their intelligence and activity have adopted, and become in the best sense a civilized nation." ${ }^{14}$ The respect continued with Japan's victory over Russia in 1905 . One author stated that the Japanese victory caused "a wave of awe"15 to go around the world. It was of course believed that it was with the aid of Western learning (especially military technology) that Japan was able to achieve victory, and this victory showed that Japan had fully grown by using the glory of Western civilization. Japan's victory had made the world fully aware not only of Japan's power but of its ambitions.

While Japan received the respect it so desperately wanted, it came with a cost; the Japanese victories led to a growing fear of Japan in the West. By rising up to the level of the big powers, Japan was now considered a competitor. Akira Iriye framed Japanese-American relations between 1895 and 1917 as those of rivals. ${ }^{16}$ This narrative is supported by popular writings at the time. In particular, businessman and author Carl Crow wrote in 1916 that American and Japanese interests were on a course to clash, with the possibility of war. While Crow noted that "in their hearts the Japanese believe themselves the superiors of the Americans in everything except wealth, ${ }^{17}$ he also

\footnotetext{
${ }^{14}$ White, The War in the East, 671.

${ }^{15}$ Sydney Tyler, Great Battles of History Vol. V, The Japan-Russia War (Philadelphia, P.W. Ziegler Co., 1905, 557.

${ }^{16}$ Akira Iriye, "Japan as a Competitor, 1895-1917," in Mutual Images, Essays in American-Japanese Relations, ed. Akira Iriye (Cambridge: Harvard University Press, 1975), 73.

${ }^{17}$ Carl Crow, Japan and America, A Contrast (New York: Robert M. McBride \& Co., 1916), 302.
} 
believed that conflict could be avoided with better dialogue between the two countries. ${ }^{18}$ The countries were rivals, but cooperation could exist with diplomacy.

The other factor working against Japan was the re-emergence of old worries of a so-called Yellow Peril. The Yellow Peril had once been Caucasian fears of being overrun by Chinese immigrants in the American West during the mid-nineteenth century, which led to the passing of the Chinese Exclusion Act in 1882. In the aftermath of the RussoJapanese War the Japanese had become the new face of the old racist fears in America. In a 1919 book titled The Truth about China and Japan, B. L. Putnam Weale called out Japan for its blatant imperialism. Weale labeled Japan's attempt to spread east as the Japanese Monroe Doctrine, and described it as "not the protection but the subjection of the East. ${ }^{19}$ Though not as explicit, the sentiment was echoed by McKenzie, who wrote that the exclusion and discrimination toward the Japanese early on would be "stored up in the long memory of a people who never forget.." ${ }^{20}$ This historical insult would combine with "the combined blood of Mongol and Malay flowing in Japanese veins gave at once the temper to brood over, the passion to resent, and the racial power to rise above European estimates."${ }^{21}$ While McKenzie gave an excuse for its existence, he still sounded the alarm of the coming Yellow Peril.

This is not to say that all discussion of the Japanese was negative during the early twentieth century. For example, Theodore Roosevelt stated in 1915 that "nothing is

\footnotetext{
${ }^{18}$ ibid, 5.

${ }^{19}$ B. L. Putnam Weale, The Truth about China and Japan (New York: Dodd, Mead \& Co., 1919), 154.

${ }^{20}$ McKenzie, The Unveiled East, 8.

${ }^{21}$ ibid.
} 
more important to the future of all the civilized communities that border on the great Pacific Ocean than that the United States and Japan should work hand in hand for the development of mankind on the basis of national self-respect and mutuality." ${ }^{22}$ The idea of a Yellow Peril was also called out as nonsense jingoism by Helen Barrett Montgomery, a Baptist social reformer who had lived in Japan and authored The Empire of the East. Montgomery only foresaw a Japanese-led "Yellow" threat to trade, not American civilization. ${ }^{23}$ Speaking to American hostility toward the Japanese in 1915 , the former president of Vassar College asked for patience from the Japanese because the U.S. had an immigrant problem on the East Coast (mostly from Italians) that tainted the image of all immigrants in America. ${ }^{24}$ California was only afraid of suffering the same fate as the Eastern states.

In popular discourse as evidenced by newspapers and fiction, the impression of the Japanese shifted drastically. A 1937 study of American opinion toward Japan, based mostly off newspapers, shows a very similar pattern as the other literature: an approval of Japan before the Russo-Japanese war, and wariness or fear afterward. The largest difference in this study is that newspapers showed that "after the Japanese had been excluded from this country by the immigration law of 1924, the American public refused to be excited about the [Far Eastern] question." ${ }^{25}$ What is more, the authors claimed that "when the Sino-Japanese war began September 18, 1931, the average American

\footnotetext{
${ }^{22}$ Lindsay Russell, ed. America to Japan (New York: The Knickerbocker Press, 1915), 18.

${ }^{23}$ Montgomery, The Empire of the East, 227.

${ }^{24}$ Russell, America to Japan, 152.

${ }^{25}$ Eleanore Tupper \& George E. McReynolds, Japan in American Public Opinion (New York: The MacMillan Co., 1937), 443.
} 
knew little about the Far East or the issues involved."26 This phenomenon also appeared in popular fiction, where Charles B. Wordell noted that Japanese representation in fiction declined because "Americans knew too much about Japan to be satisfied with mere recitation of customs and landscape; and the Japanese people were proving too assertive and successful to be forced into passive roles."27

\section{Lingering Concepts}

The concepts of each country changed drastically in the American cultural psyche during the early years of the twentieth century. The old image of opulent and prideful China was fading away into an image of an upstart underdog people, while the image of Japan progressed rapidly from a curiosity into a fast-learning student and eventually into a competitor and threat. The result of these transformations was that, by the 1930s, the American opinion of these countries was - when present at all usually in favor of China. Possibly due to the order of interaction with the U.S. or the promise of more trade, Americans were more interested in seeing China develop than seeing Japan gain an empire. When coupled with the fact that the Japanese had become the focal point of xenophobia in America more recently than the Chinese, sympathy toward China outweighed sympathy for Japan by the 1930 s.

\section{The Official Western Response}

\footnotetext{
${ }^{26}$ ibid, 444.

${ }^{27}$ Charles B. Wordell, Japan's Image in America, Popular Writing about Japan, 1800-1941 (Kyoto: Yamaguchi Publishing House, 1998), 198.
} 
To place the responses from both Japan and China in context, a brief overview of the official Western response to the Manchurian Incident of September 1931 is required. The two responses relevant to our discussion are the Stimson Doctrine, articulated by the U.S. Secretary of State Henry Stimson in February of 1931 and clarified for both countries in 1932, and the result of the League of Nations sponsored investigation into the Manchurian Incident, the Lytton Report. Both responses effectively sided with China and called for the re-establishment of China's territorial and sovereign borders.

The Stimson Doctrine was not an indictment of Japanese actions nor was it an outright support for Chinese defense. The Doctrine instead focused on the interests of the United States, particularly on its ability to trade freely with all current trading partners. In essence, the Doctrine was a statement that the U.S. government would not recognize any new states created by conquest or war. In the initial announcement, Secretary Stimson made it clear that liberated or returned countries would be accepted (even if the liberation requires violence) provided that the new government is established by the will of the people. ${ }^{28}$

What the Stimson Doctrine was opposed to, however, was imperialism. According to a U.S. Government note to China and Japan on January 7, 1932, the U.S. would not recognize any "de facto" situation nor would it recognize "any situation, treaty, or agreement which may be brought about by means contrary to the covenants and obligations of the Pact of Paris of August 27, 1928, to which both China and Japan,

\footnotetext{
${ }^{28}$ For example, Stimson references the Guatemalan takeover by General Orellano as a rebellion that was not recognized, but the following constitutional government was.
} 
as well as the United States, are parties." ${ }^{29}$ The message plainly stated that the U.S. would not recognize any changes to the status quo in Asia, especially if those changes threatened the Open Door policy.

The League of Nations created and sent The Lytton Commission to Manchuria in late 1931 to investigate the Japanese claims of a Chinese-instigated Mukden Incident. The Commission presented its results on October 1, 1932 to the League with several suggestions to resolve the matter peacefully. Though seen as a victory for China because Japanese claims of self-defense were not substantiated, the report still called for change in Manchuria. One important aspect is that the report recognized Japanese interests in Manchuria, stating that they "were facts that could not be ignored, and any resolution which failed to recognize them and to take into account also the historical associations of Japan with that country would not be satisfactory. ${ }^{30}$ Further, the report also admitted that the Chinese claim of sovereignty over the area was tenuous, and therefore an autonomous state would best suit the needs of all parties. ${ }^{31}$ The report also, implicitly, refuted the Japanese claim that Manchukuo was already autonomous.

The result of the Lytton Commission, along with the lack of recognition from the U.S., was that Japanese aggression was left as the sole villain in the story. While the League recognized Japanese interests in Manchuria as well as the limitations of Chinese

\footnotetext{
${ }^{29}$ Quincy Wright, "The Stimson Note of January 7, 1932," The American Journal of International Law, Vol. 26, No.2 (1932): 342.

30 "Appeal by the Chinese Government, Report of the Commission of Enquiry" (1932); Page 130, accessed March 7, 2015, http://www.wdl.org/en/item/11601/.

${ }^{31}$ ibid.
} 
sovereignty in the area, the aggression of Japan - flimsily justified by the Mukden

Incident - was held to be inexcusable. In order to defend their case, the Japanese would therefore have to refute claims of militarism while simultaneously attempting to legitimize their actions. China, on the other hand, would have to continue to decry Japanese aggression while simultaneously building its case for sovereignty over the area. Neither statement by Western powers was strong enough to be considered complete support of one side or the other. Instead, the stage was set for both the Japanese and Chinese to present their cases to the world at large. Because of the primacy of the United States and the fact that it was not a member of the League of Nations, a special effort was made by both sides to persuade Americans.

\section{Part II: Marketing to the Masses}

In preparation for and in response to reactions from Western powers, China and Japan produced various forms of English language material to state their case. Imperial Japan was no slouch at marketing its success to the rest of the world. For example, the Japanese used World Fairs as a means to "sell" their culture and heritage, or at least the myth thereof. ${ }^{32}$ Japan had been building a commercial empire on the continent since its gains from the Russo-Japanese War, and had quickly accelerated after taking over German rights following Germany's collapse from World War I. The Japanese expanded their empire by employing railway imperialism in mainland Asia beginning in the 1910 s.

\footnotetext{
${ }^{32}$ Coincidentally, this marketing of international prestige and myth-making eventually became a gateway for Japan to push the myth of its 2,600 year empire, which became important in the coming conflicts. For more info on Japanese in World Fairs, see "All the World a Melting Pot?" by Neil Harris in Akira Iriye ed. Mutual Images, p. 24-55.
} 
${ }^{33}$ This early start gave Japan a chance at producing works in the 1920s aimed toward an American audience for both commercial and tourist purposes.

China, for its part, was new to the stage of international prestige but enjoyed one valuable asset: the first lady, Madam Chiang Kai-shek, Soong Mei-ling. Her American upbringing and education, not to mention her prominent Christianity, made her relatable to Americans. When combined with her involvement in the higher levels of the nationalist Kuomintang (KMT) government, Madam Chiang Kai-shek became an easy conduit to connect problems in far-away China with American audiences, which consequently made her a celebrity in America. Her celebrity was exemplified by her and her husband's appearance as the Time magazine Persons of the Year in $1938 .^{34}$ Additionally, Chinese Christians had been pushing for greater acceptance of Chinese in America for decades before the conflict between China and Japan worsened. After limitations were placed on Chinese immigration in 1882, there was a movement amongst many Chinese to increase global understanding of Chinese affairs in an attempt to preserve their fading sovereignty. Though it was not as unified as the Japanese effort, there were many Chinese groups that made efforts to integrate China into the international system, and to learn the art of international public relations.

Madam Chiang Kai-shek's celebrity and various less-prominent Chinese efforts notwithstanding, Japan had been hard at work maintaining connections in America both

\footnotetext{
${ }^{33}$ Railway Imperialism is the process of controlling an area through ownership of the railroads. Imperialists would spread their ownership of land and their influence under the guise of expanding trade. 34"Man \& Wife of the Year." Time 31, no. 1(January 3, 1938): 14. Academic Search Premier, EBSCOhost, accessed May 11, 2014.
} 
economically and diplomatically for longer than the Chinese had. The Japanese advantage was partly because China had suffered heavily from warlordism for much of the preceding fifty years, whereas Japan enjoyed a unified front on the international scale since the Meiji Restoration. This advantage allowed Japan to act in a more politically consistent manner than China, for better or worse. This discrepancy is reflected in the works published by agencies promoting the benefits of each country's interpretation of the situation to sway American audiences.

\section{Japan}

The Japanese efforts were early and concentrated. Through its vehicle of expansion, the South Manchuria Railway (SMR), Japan began a campaign to convince the world of the progress they were making in Manchuria in 1922, long before the creation of Manchukuo. ${ }^{35}$ The SMR-published book Manchuria: Land of Opportunities (1933) is a masterpiece of ego-baiting platitudes towards Americans. The book, printed in the United States, focuses on two factors of Manchuria which were of interest to Americans - namely those of untapped material wealth and business opportunities. Much of it focuses on the increased production brought about by the SMR, and it emphasizes that the production is made possible by American machinery: "The shriek of these American locomotives across Manchurian plains and through Manchurian cities is

\footnotetext{
${ }^{35}$ Minami Manshū Tetsudō Kabushiki Kaisha, Manchuria, land of opportunities (New York: South Manchuria railway, 1922)
} 
the voice of modern enterprise bringing a rich, modern life, opportunity, hygiene, education and happiness to an ancient people." ${ }^{36}$

At this stage in their development, the SMR was looking for investors or business partners to help expand its empire while simultaneously establishing the precedent of Japanese built modernity. Being so early in the Manchurian conflict, the SMR could be proactive rather than reactive, so they employed hyperbole and shameless pandering. One instance of this was referring to the SMR (and by extension the Japanese) "Western Civilization in the East." ${ }^{37}$ In 1928, the SMR revisited the subject by having a Western author write of how the railway had been the only reliable force in Manchuria, stating that "the fact that the S.M.R., under Japanese control, has been able to carry on cannot but be of great benefit to the industry and trade which it serves, both Chinese, Japanese, and foreign." 38

Once Manchukuo was established, however, the tone coming from Japan shifted slightly, adding a new defensive angle. The official book proclaiming the founding of Manchukuo to the West, published by the Japanese Chamber of Commerce, was much more restrained in its ambitions than the early SMR efforts, but not in its goal to demonstrate that Japanese influence was the best for the area and that Manchukuo was truly independent. The largest portion of the book focuses on supporting a theme that will be consistent throughout this study, the improvements to economic conditions

\footnotetext{
${ }^{36}$ Minami Manshū Tetsudō Kabushiki Kaisha. Manchuria, land of opportunities, 69.

${ }^{37}$ Minami Manshū Tetsudō Kabushiki Kaisha. Manchuria, land of opportunities, 68.

${ }^{38}$ Henry W. Kinney, Modern Manchuria and the South Manchuria Railway Company (Tokyo: The Japan Advertiser Press, 1928), 24.
} 
since Japanese intervention and investment prior to the war - specifically on the production of soy (or soya) beans and coal. In this book, it appears that the Japanese were planning for a long-term future for the country by selling twenty-year bonds. ${ }^{39}$ The work also briefly defends Japanese actions by claiming Manchurians were economically repressed by a bandit warlord and Japan was only playing the assistant to liberation, much like the French did to the United States. ${ }^{40}$

Having already made a connection to America and the frontier, Japan asked a fairly honest question of why it was acceptable when Western countries expanded, but not Japan. When, exactly, did imperialism become, as Yamamuro puts it, anachronistic? ${ }^{41}$ For the Japanese, it seemed especially hypocritical when Britain still held Hong Kong and France still controlled Indochina, despite having been acquired in a means not unlike what Japan was trying in Manchuria. However, celebrating basic imperialist principles was no way to win sympathy, so Japanese rhetoric pursued a different tactic by asking why not Japan? With Japan's status as a rising country in the international system, who better to take care of China while she was struggling to survive than Japan? Dr. Roy Akagi - who had received a PhD in history from Harvard asked this exact question at a luncheon discussion for the Foreign Policy Association in 1932:

\footnotetext{
39 Japanese Chamber of Commerce of New York. Manchukuo; the founding of the new state in Manchuria (New York: Japanese Chamber of Commerce, 1933)

40 Japanese Chamber of Commerce. Manchukuo; the founding, 3.

${ }^{41}$ Yamamuro Shin'ichi, and Joshua A. Fogel, Manchuria under Japanese Dominion (Philadelphia: University of Pennsylvania Press, 2006).
} 
As next-door neighbor of China, Japan occupies a unique position with regard to Manchuria which Western powers do not occupy. Let me illustrate this. In our relationship with our neighbors, proximity or distance between the parties concerned is a great factor. If your next-door neighbor's habits are distasteful and disorderly, quarrelsome and noisy; if he borrows money from you but never dreams of returning it, not even of accounting for interest accruing thereto; if he keeps untamed cats which will rob you of your nightly sleep; if he harbors undisciplined dogs which insist upon biting the members of your family; and if, when your patience is exhausted, you ring the bell of your neighbor and discover that there is no responsible master in the house, then you will be vitally concerned with the whole situation which your friends ten blocks away or beyond the city limits can calmly look on, theorize, and even tender ideal advices. Japan ... occupies just such a position. ${ }^{42}$

How could Americans, who were satisfied as long as the ruling regime in China kept the Open Door policy intact, possibly understand the unease that Japan felt toward a chaotic China? Was the Japanese response really any different than the American interventions in Mexico not twenty years prior? These arguments were used by Japanese speakers in an attempt to gain an understanding with American audiences on an ideological level. By comparing Japan and America, this method outlined the similarities between the two countries.

A unique point of emphasis in Japanese claims was that of Chinese banditry. Banditry had been used as a justification for military action in China for centuries, and the act of labeling rebellious Chinese groups as bandits in an effort to discredit their legitimacy was grasped wholeheartedly by the Japanese. K. K. Kawakami, in his defense of Manchukuo, wrote that banditry was so entrenched in China as to become a class, "almost as much as the gentry, the peasantry, or the trading class." ${ }^{43}$ However, the Japanese Army, unlike the warlords who ran Manchuria before, had the ability to stop

\footnotetext{
${ }^{42}$ Manchuria, discussed by Roy H. Agaki, T.Z. Koo, Joseph P. Chamberlain, January 23, 1932. Pamphlet published by the Foreign Policy Association. Found in the Frank Williston Papers, University of Puget Sound Archives, Collins Memorial Library.

${ }^{43}$ K. K. Kawakami, Manchoukuo: Child of Conflict (New York: Macmillan Co, 1933), 235.
} 
the "reprehensible" practice of buying the bandits and instead balance repression of banditry and rehabilitation through state programs. ${ }^{44}$ The Japanese ambassador to the U.S. stated in 1934 that "Manchoukuo of today has [...] been purged of the timehonored social venom and is on the road to an era of law and order." ${ }^{45}$ Not only were the Japanese more able than the Chinese to administer the area, but they were the only ones amongst the first tier countries with the ability and willingness to do so.

The final avenue of defense for the Japanese was to claim that they were the victims of international discrimination. An initial explicit example of this is in Matsuoka Yosuke's speeches to the League of Nations hearings on the Manchukuo matter, which resulted in him leading his delegation out of the League entirely. Matsuoka defended Japan's position as a contributor to internationalism, stating that placing Japan "on a lower plane ${ }^{\prime 46}$ had unfairly limited Japan since the beginning. Matsuoka went so far as to compare Japan to Jesus in a December 1932 address to the League of Nations, stating that Jesus, like Japan, was also misunderstood in his time and crucified for it. Though he later retracted these remarks, they are a striking example of the level of hyperbole Matsuoka would employ. ${ }^{47}$ The victimization only increased as Japan's fighting in China

\footnotetext{
${ }^{44}$ Kawakami, Manchoukuo: Child of Conflict, 237.

${ }^{45}$ Hirosi Saito. "My Impressions in the Far East and Japanese-American Relations." Delivered at the Academy of Political and Social Science, Philadelphia, PA. November 23, 1934. Found in Williston Papers. 46 "Japan's case in the Sino-Japanese dispute as presented before the Special session of the Assembly of the League of Nations," Accessed March 5, 2015, https://archive.org/details/japanscaseinsino00leag.

${ }^{47}$ The Manchurian Question; Japan's Case in the Sino-Japanese Dispute as Presented Before the League of Nations, address given by Yosuke Matsuoka, Delegation to the League of Nations, December 8, 1932. Printed in report labeled the same.
} 
progressed: in a proposition for a new cultural League of Nations, the president of the Nippon Cultural Federation stated that

"Contrary to our expectations, [...] we Japanese have invariably received discriminative treatment, highly irrational and inhuman, at the hands of foreign powers in the problems of racial equality, emigration, national defense and so on. It was simply for the cause of world peace and international harmony that we Japanese had stood firm for many years under such a displeasing and humiliating situation with extraordinary patience. However, we were driven at last to make a choice between the two alternatives: either to renounce forever our timehonored national ideal and to yield ourselves up to the nominal pacifism actuated by absurd and inhumane ideas or to uphold our national ideal with determination." ${ }^{48}$

No longer was the treatment of the Japanese simply unfair, it was intentionally discriminative to hold the Japanese down. The only way that Japan could guarantee fair treatment would be to create another League of Nations in Asia.

Though playing the victim of international racism was a last resort for the Japanese, it still played an effective role in their rhetoric. The major themes of Japan's message to the Western world were based in Japan's ability to offer the security and growth in China that only a top-tier power could offer, and that the autonomous Manchukuo government was proof of Japanese benevolence. It served the Japanese better to maintain this image of modernity and prosperity. However, when all else failed the Japanese could always decry the systematic inequality that was keeping them from fully protecting their sovereignty.

\section{China}

${ }^{48}$ Gaku Matsumoto, The Cultural League of Nations; proposition (Tokyo: Nippon Bunka Renmei, 1936) 7. 
China, being the defender in this scenario, did not produce any official works discussing the Manchurian situation prior to Japanese invasion and yet there were many advocates for China in the early twentieth century who did publish books on Japanese commercial imperialism. While Japan - as a member of the first-tier nations - claimed superiority and benevolence in a chaotic land, China instead claimed that its shortcomings were exaggerated and that Japan's aims were purely imperialistic. Publications from the private sector followed much of the same rhetoric as official government-sponsored works by choosing to focus on Japan's aggression and failures while glossing over internal struggles. Where they differ is in the discussions of ideology and morality.

In response to the outbreak of fighting in 1931, China United Press released a voluminous tome attacking the whole scenario titled The Puppet State of "Manchukuo" ${ }^{49}$ in 1935 . Though this work is not officially supported by the KMT, it is interwoven with official statements and speeches by the likes of Chiang Kai-shek in response to Japanese actions. The authors claim that Japanese aggression has long targeted China and is a result of "several centuries of teaching by Japanese warriors." 50 The book addresses claims of banditry by explaining that the Japanese military had started and trained bandits in the area to destabilize Chinese rule as early as $1916 .{ }^{51}$ It also addressed the economic claims which Japan so heavily leaned on, claiming that

\footnotetext{
49 The puppet state of "Manchukuo" (Shanghai: China United Press, 1935)

${ }^{50}$ The puppet state of "Manchukuo" (Shanghai: China United Press, 1935), 4.

${ }^{51}$ ibid, 86.
} 
Manchukuo unsustainably burdened Japan because nobody would trade with the new country besides Japan. ${ }^{52}$ Further, the authors derided Japanese immigrants because they failed to understand the land in China and farmed it improperly. Most importantly though, the bulk of this book is dedicated to how Japan broke international treaties and bullied China in to signing unfavorable agreements. This book is evidence of China's official statement on the conflict with Japan, which played the opposite position of Japan.

Chinese authors were not content to label Japanese aggression as simply economic. Instead, the rhetoric focused more on identifying the Japanese as militarists to whom aggression was a way of life that could not be satiated. In an article titled “Whither Manchuria?” from 1932, Ching-Chun Wang goes so far as to turn Japan's claims of stabilizing the continent from Soviet influence back on them, stating that "nothing will do more to foster Sovietism in the Far East than Japan's wanton aggression." ${ }^{53}$ In a 1937 address delivered before the Foreign Policy Association of New York, Hu Shih stated that the causes of the conflict in the Far East were "the clash of Japanese imperialism with the legitimate aspirations of Chinese nationalism" and "the conflict of Japanese militarism with the moral restrictions of a new world order." ${ }^{54}$ Being the victim of aggression meant that Chinese authors and those that supported them were free to attack Japanese policy.

\footnotetext{
52 ibid, 163.

53 "Whither Manchuria?" Ching-Chun Wang. The World To-day (London: February, 1932), 13. Found in Williston Papers.

54 "The Issues Behind the Far Eastern Conflict," Hu Shih, delivered November 13, 1937. Transcript found in the Williston Papers.
} 
The associate director of the China Institute in New York, Chih Meng, published a book in 1932 called China Speaks which was dedicated to countering Japanese claims. China Speaks clearly lays out the importance of Manchuria to the Chinese, both geographically and culturally, and how the Japanese claims of a disputed land and wasted potential are false. The most unique point in China Speaks is that Japan was using the methods of the past: "one significant revelation from the crisis is that the ideas and methods of Japanese diplomacy belong to the last century. ${ }^{155}$ Meng outlines the imperialist steps that the Japan had taken, like pre-emptive defense and geographical propinquity, to show how much Japan was acting like nineteenth century imperialist powers, which was in direct opposition to the spirit of internationalism agreed upon by the world powers after WWI. China's basis for defense against Japan was firm, and China Speaks exemplifies the Chinese method of simply arranging the facts against Japan and placing them in the larger context of global politics.

Unlike Japan, where heterodox religions had historically been policed closely, Christianity had been growing in acceptance since being forced open due to the Opium War. In the twentieth century, the largest evidence of China's increasing adoption of Christianity was Madam Chiang Kai-shek and the baptism of Generalissimo Chiang Kaishek - though it was understood to have been largely symbolic in his case. The point remains that the two largest faces of China on the global scale identified as Christian.

\footnotetext{
${ }^{55}$ Chih Meng, China Speaks (New York: The MacMillan Co., 1932), 118.
} 
This identity gave the Kai-sheks yet another avenue to identify with westerners, one which they used prominently.

While the Japanese tried to use their modernity to transcend the racism and exclusion between the West and Japan, the Chinese used Christianity to claim the moral high ground. Look no further than a 1937 pamphlet from the China Information Committee, which states: "no true Christian could decline" the call for aid in China where over 300,000 Christians currently resided. ${ }^{56}$ Because China was painting itself as the victim of militarism and wanton aggression, the appeal to Christian generosity and good nature was a logical next step. Additionally, the hope to convert hundreds of millions of Chinese was a strong draw for American Christians.

\section{Security vs. Freedom}

The messages presented to Western audiences from both countries were both opposite and complementary. Japan asserted its rights and the light of the "Lamp of Industrialism ${ }^{\prime 57}$ that it could spread over the underdeveloped China, while the Chinese downplayed fears of their lack of control and played up the ethical and moral aspects of their defense. While the Japanese method could hardly be said to have succeeded, it did at least have the enticing concept of suppressing Chinese and Soviet rebellions through a Japanese hegemon. Despite their claims, the debate around the security of China from the Soviets was hotly contested. If the ultimate American fear was the closure of China

\footnotetext{
56 "Japan's Invasion Engulfs China in Horror and Sorrow," The China Information Committee, Hankow, China: 1937. 26. Found in Williston Papers

${ }^{57}$ Manchuria, discussed by Roy H. Agaki, T.Z. Koo, 4.
} 
and the unification of the world's largest population against them, Soviet ideology was a greater threat than the Japanese, with whom the U.S. could negotiated.

What is thought-provoking about these arguments is that representatives from both countries acted hypocritically. Japan used the international structure to decry China's weakness as a threat to the League of Nations ideal of peace while glossing over its own shortcomings and militarism. China, meanwhile, very publicly decried the international system as an instrument of its repression, ${ }^{58}$ but eagerly appealed to that same system when Japan began aggression against China. Both sides used the standards of the international system and the ideals of the League of Nations to defend their position and attack the other side. Both sides also tried to play to Western understandings of Asia. Japan did so by trying to act as a Western power which could increase trade from the area, and China did so by rallying against aggression as the ultimate flaunting of the League of Nations' ideals and pandering to cultural or religious similarities.

From official publications or speeches given by government employees to private experts on the conflict, both Japan and China attempted to rally American support for their side. The effect that these works had on the general populace is debatable, but the point remains that they were published in English and read by interested parties in

\footnotetext{
${ }^{58}$ The May $4^{\text {th }}$ Incident may be the most notorious, but China's dissatisfaction with the international system is well documented. See Zhang Yongjin, China in the International System,1918-20: The middle Kingdom at the Periphery
} 
America. We know that, to academics and other interested American parties, this conflict was perceived important enough to fill several books.

\section{Part III: Western Authors}

While Japan and China were making their cases on both the diplomatic and popular fronts, the Western world was abuzz with indications of the conflict in Asia. The post-World War I international society was focused on keeping the peace over all else. Therefore any conflict between League of Nations members -as both China and Japan were - or any conflict that threatened to disrupt the world order, was a point of focus. Since China had the largest population in the world at the time and was an extremely valuable trade partner to much of the Western world, and America in particular, any threat to the Open Door would garner substantial attention. Additionally, Japanese imperialism could become not only a threat to global peace, but a threat to the hegemony of Western nations.

\section{Pro-Japan}

There were some, however, who viewed the Japanese from another angle. These authors, usually American, praised the idea of Japanese leadership in Asia. If the Japanese could finally put China in order after almost a century of instability, while simultaneously keeping the Open Door policy intact, why should they be stopped? The international system was based on the ability to trade, and unfettered access to China had been the dream of the West since the Opium War. The only thing limiting that 
dream at this point was the instability in China and a lack of infrastructure to fully utilize China's resources. The Japanese proved with their development of Manchuria that they were able to offer just that. The Japanese could use their special position as Westernminded Asians to finally put Asia in order.

These were the arguments used by those who wrote in favor of Japanese leadership in Asia. It should therefore be no surprise that some of these Western authors found themselves on the payroll of Japan or Manchukuo. One such writer was George Bronson Rea, a former U.S. Army captain and prominent writer of the Far Eastern Review, an English newspaper based out of Shanghai. Rea was hired as the special advisor to Washington for Manchukuo soon after its founding and wrote several works aimed at American audiences to implore them to support the new country. Being an American meant that Rea was in no way beholden to the diplomatic constraints of a foreign national, which showed in his direct criticism of American policy in Asia. He criticized U.S. concern with the preservation of China as a sovereign nation despite its humanitarian disasters, stating "there is something wrong with a policy which countenances such inhumanity merely to keep this country intact under any form of government to maintain equity of trade. ${ }^{159}$

Rea even goes so far as to call back to the era of Western imperialism in the Qing, when the policy of keeping China weak was used for exploitation. He states “I sometimes wonder just how far our own vacillating policies are responsible for the

${ }^{59}$ George Bronson Rea. The Case for Manchoukuo (New York: Appleton-Century, 1935), 19. 
failure of China to establish a strong, central government, capable of uniting the scattered provinces into a compact whole.." ${ }^{10}$ Rea's argument was quite simply that America had cared little for China outside of keeping the Open Door policy intact, regardless of consequence for China's neighbors. The lack of external support led Japan on the course of securing China on her own, which has been handled benevolently with the creation of the autonomous Manchukuo. Rea's criticism of American policy in Asia can be summed up as "good commercial policy, but poor principle." ${ }^{61}$ In a similar vein, history professor at Clark University and authority on international relations George H. Blakeslee wrote in the journal Foreign Affairs that Japanese and American policies were very similar because they both make it their responsibility to secure peace in their surrounding areas, "a responsibility which other Powers have appeared to recognize in the case of the United States, but have not recognized in the case of Japan." ${ }^{62}$

As critical as Rea was of American policy, he at least attempted to be objective regarding the complex problems China faced. Others, such as former president of the Throop Polytechnic Institute, ${ }^{63}$ James Scherer, had no pretense of objectivity. In his 1933 profile of Manchukuo, Scherer openly stated that Japan was saving China from itself by embracing Western technologies and methods in Manchukuo. Outside of the obvious economic benefits of this development, Scherer commented that by solidifying Manchuria, Japan had become the biggest defense against the spread of Communism in

\footnotetext{
60 ibid, 72.

61 lbid, 246.

62 George H. Blakeslee, "The Japanese Monroe Doctrine," Foreign Affairs Vol. 11, No. 4 (1933): 677.

${ }^{63}$ Later renamed to the California Institute of Technology. 
Asia. Because of Japan's role of securing China, Scherer stated that "Japan is the spearhead of the West in the Orient. ${ }^{\prime \prime 4}$ Though Scherer understood the distrust of Japan after its blatant imperialist actions in Korea, he reassured Americans that Manchukuo was different from Korea because it was a true liberation and a founding rather than a subjugation, which showed a more progressive Japan. ${ }^{65}$

A similarly favorable view of Manchukuo can be found in a much more visual manner in the 1937 informational short film, "Manchukuo: the Newborn Empire." The film made a point to display all of the technological advances brought by the SMR and the Japanese, specifically in the advancement of agriculture and mining. Because this film was produced for a general American audience, there are comparisons to locations in America and jokes on cultural quirks. For example, when the narrator is describing a schoolroom scene: "believe it or not, these boys are writing a complete sentence" and "look at the plan on the blackboard: it starts at the right and reads to the left!" ${ }^{66}$ The cultural link with America is extended by showing the popularity of America's national pastime, baseball, among both Chinese and Japanese. The film ends with a contrast between the old and the new on the Yalu River while stating that the real cause for the conflict in Manchuria was economic in nature. ${ }^{67}$ The film implies that Japanese actions in Manchuria have been costly but worthwhile.

\footnotetext{
64 James A. B. Scherer, Manchukuo A Bird's-Eye View (Tokyo: Hokuseido Press, 1933), 78.

${ }^{65}$ Scherer, Manchukuo A Bird's-Eye View, 112.

${ }^{66}$ Beaux Art Productions. "Manchukuo: the Newborn Empire." The Internet Archive, 13:09, Accessed March 7, 2015. https://archive.org/details/manchukuo_the_newborn_empire.

${ }^{67}$ ibid.
} 


\section{Pro-Diplomacy}

There were some, however, who were openly critical of Japanese aggression while still not fully supportive of the Chinese Nationalists. H.G.W. Woodhead, editor of the Shanghai Evening Post and Mercury, stated that while the Chinese people were in no way supportive of the Japanese or Manchukuo governments, it was quite possibly a better option than an absentee KMT or Communist control. ${ }^{68}$ Woodhead understood the failures of the Chinese government to properly secure their borders from warlords and bandits, and even though the Japanese militarism was overwhelmingly a bad thing for China overall, it is possible that in its wake the Chinese who lived in Manchuria could get a better life.

Another method of defusing the situation was by using the similar suggestions to the Lytton Report by proposing a diplomatic solution. A 1936 conference entitled "Problems of the Pacific" discussed the cause of and solutions to problems in the Pacific, and concluded that the true failure was the lack of flexibility in the Western-dominated treaties, specifically the Washington Conference and the subsequent Nine Power Treaty - a 1922 treaty which attempted to legally solidify the Open Door policy. By not accounting for the development of Soviet Russia and her interests or the economic and strategic ambitions of Japan, the treaties were doomed to fail. Therefore, Japan was forced to "challenge the supremacy of Western nations and force them to grant her recognition as a major Power whose interests could not be thwarted or ignored with

\footnotetext{
${ }^{68}$ H. G. W. Woodhead. A Visit to Manchukuo (Shanghai, China: Mercury Press, 1932), 86-91.
} 
impunity. ${ }^{\prime 69}$ Though Japanese actions were deemed as not acceptable, the fault lay more with the international system than with Japan or China.

The one threat on which this 1936 conference agreed with Japan was that of communism. However, even there the conference sided with the League of Nations; the best defense would be a proper joint action with China. This type of discussion downplayed Japanese actions in favor of discussing larger systematic failures, but was still critical of the Japanese aggression and any ideal that justified said aggression. By criticizing both sides of the dispute, this discussion took the League of Nationssupported middle road of diplomacy and bilateral agreements as a solution.

\section{Anti-Japan}

There were also those who were openly critical of the Japanese. Much like the League of Nations, criticism of Japan was largely focused on the increased militarization and aggression in mainland Asia. However, criticisms were also lobbed at the abject failures of Japanese economic expansion. When evidence of Japan's economic struggles surfaced, the Japanese rhetoric, which was largely based on the claims of economic security, rang hollow. If Japan's economic claims were exaggerated or entirely false, then the only reason for expansion was blatant imperialism.

Journalist Upton Close stated as much in his exposé on Manchukuo, frankly doubting the ability of Japan to maintain the façade of Manchukuo because of how

\footnotetext{
${ }^{69}$ W.L. Holland and Kate L. Mitchell, eds. Problems of the Pacific, 1936 (Chicago: University of Chicago Press, 1936), 186.
} 
much money it was losing. Close wrote that if the financing structure "is carried on three more years, the debt service alone will more than consume the entire income of the national treasury." ${ }^{70}$ Close's prediction was confirmed in 1937 in the Far Eastern Survey journal, where the troubled Japanese economy was explained as "disequilibrium in Japan's international financial position as actually exists must be ascribed not to foreign trade restrictions but to the consequences of her own deliberate policy in Manchoukuo." ${ }^{\prime 71}$ Regardless of whether Japan's justifications were legitimate or not, the propping up of Manchukuo was just too much for the fragile Japanese economy to handle. Logically, if Japan could not maintain what it already had, how could it have been of any help to the rest of China?

Perhaps due to the fact that it was not a member of the League of Nations, criticisms of Japanese aggression were abundant in the U.S. In 1938, the American Committee for Non-Participation in Japanese Aggression printed a booklet collecting the statements of many influential people titled America's Share in Japan's War Guilt. The booklet included statements from President Roosevelt, the current and former Secretary of State, and other politicians decrying American support of Japan. As one would expect, the book demonized Japan's attacks and America's sale of war materiel to Japan, stating "China is making a magnificent struggle for liberty. The least we can do is

\footnotetext{
70 Upton Close, “Banzai, Manchukuo!” The Saturday Evening Post, February 25, 1933, 58.

${ }^{71}$ Elizabeth Boody, "Manchoukuo, The Key to Japan's Foreign Exchange Problem," Far Eastern Survey Vol. 6, No. 10 (1937): 107-108.
} 
to withhold aid from her enemy." ${ }^{\prime 2}$ The booklet quotes the assistant Secretary of State Francis B. Sayre describing supporting Japan as "siding with the evil against the good."73 When a prominent politician brings out claims of good and evil, one can confidently say that demonization of Japan was prevalent in the U.S.

It was not only public officials and advocacy groups that criticized Japan, but foreign policy specialists as well. History professor Franz Michael, a German refugee who had spent considerable time in China, wrote in the Pacific Affairs journal that, while Japan's disregard of the treaty system proved only the inefficiency of the system, the "deplorable aspect of the invasion of China has been the utter disregard of civilian life, honor and property by the invading army." ${ }^{74}$ Michael also writes that Manchukuo is certainly a puppet government because it allows Japan to be expansionist while providing some excuse. Speaking to the Torch Club in 1935, Jacob Gould Schurman onetime president of Cornell University, Envoy to the Republic of China and Ambassador to Germany - called Japan a "menace to the peace of the world."75 In the same speech, he mocked the idea of a Japanese Monroe Doctrine, stating "the Japanese policy is a cynical travesty, a Machiavellian perversion, of the Doctrine of President Monroe." ${ }^{76}$ To some, the attempts by Japan to liken itself to the United States did not have the desired

\footnotetext{
72 America's Share in Japan's War Guilt. American Committee for Non-participation in Japanese Aggression, (New York, 1938), 4.

73 ibid, 9.

${ }^{74}$ Franz Michael, "The Significance of Puppet Governments," Pacific Affairs Vol. 12, No. 4 (1939): 400.

${ }^{75}$ Special to THE NEW YORK TIMES. "SEES REAL MENACE IN JAPAN'S POLICY." New York Times (1923Current File), May 17, 1935. http://search.proquest.com/docview/101524362?accountid=13265. ${ }^{76}$ ibid.
} 
effect; instead of gaining American trust, these maneuvers merely insulted American pride.

\section{Toward a Future without War}

The Western response to Japanese aggression in Manchuria was varied, but the unifying theme was that violence was undesirable. For those who supported Japan's claims of security and benevolence, the military element was an unfortunate necessity that painted Japan in a bad light. This belief is why authors like Scherer argued that the creation of an independent country proves that Japan was a benevolent force in Asia, particularly when compared to what Japan could have done.

For those who hoped for a diplomatic solution, the fighting in China was an obstacle to a resolution. While both the Japanese and Chinese decried the failure of the treaty system (the Japanese because it stifled them, the Chinese because it failed to protect them), there were some who believed that the system was still inherently correct, and that the treaties themselves had been inadequate to prevent friction. The solution, therefore, was more adequate treaties. Others asked to share the blame with American diplomacy and war profiteering. Additionally, there were many like Schurman who blamed Japanese aggression squarely on the Japanese and their imperialistic ambitions. The fact remains that the overwhelming consensus in all discussions on the conflict between China and Japan was that the Japanese had broken both international rules and the peace by succumbing to militarism. 


\section{Section IV: Conclusion}

If Japan's core claim was economic in nature, China's was based on justice. The opening salvo for both countries showed a concerted effort to get America to support their side, though by different means. Japan played to American egos and economically minded people, while keeping the focus on their actions small (Manchuria was not secure, Manchuria was not really a part of China, Japan was only securing its interests). China, on the other hand, was trying its best to play the global chess game of the League of Nations and to keep the focus on the larger picture (that Japan was slowly invading China like an imperialist of yesteryear). America, not a member of the League itself, was in an odd position. It was in America's interests to keep the peace, as it was best for trade not to have to pick sides; therefore, it was wary of Japan's aggressiveness. However, Japan's aggression was not without benefit. A trusted and established trade partner was gaining more capital with which to trade. China was itself on the path of unification and becoming a better trade partner, but was riskier than Japan in that respect.

Assessing this scenario, it seemed that the Far East problem was a problem of the global community which would sort itself out, like the problems in Europe. Unlike Europe, however, there was a sense of American responsibility for peace in Asia, even more so than other Western powers, due to perceived American impartiality. Therefore, both Japan and China pleaded their cases directly to America. Both countries used a similar tactic; Japan and China were both trying to play and win within the boundaries 
set by the Euro-American imperialistic hegemony over the globe. Additionally, Western authors joined the conversation to propose solutions. While these solutions were varied in their support or criticism of Japan, they all agreed that peace and cooler heads should prevail.

Though the Japanese put out a unified and concerted effort to garner favor, the overall American opinion represented here does not side with Japan. While there were those who supported the creation of a partner empire in Asia, which could simultaneously unlock China's riches while also repelling the Soviets, most people were far more cynical. Despite the appeal of Japan's promises of increased security and access to resources without any American effort, it may have been seen as too good to be true; Americans did not take the bait. Even those who attempted to avoid demonizing the Japanese still called for a return to pre-1931 status quo. The majority of people who focused on foreign policy outright decried Japanese aggression, going so far as to call for a unified action to stifle Japanese imperialism. While China's efforts were no doubt a factor in American opinions, Japan was a victim of both poor timing and its own success. Whatever the reason, the general American opinion of Japan began to fall after 1905 and had reached an all-time low by 1931. 


\section{Chapter 2 - The Orient and the Rose City}

"Japan aims at the stabilization of the Far East through conciliation and cooperation between Japan, China and Manchoukuo for their common prosperity and well being"77 declared the Japanese Consul for Portland, Oregon, Kwan Yoshida, at a luncheon held by the Portland City Club in 1937. The consul had been invited to discuss the conflict in the Far East and its ramifications in America. Yoshida spoke of the peaceful aims of Japan in Asia, and pleaded with his audience to understand that "In China, reconstruction and unification are still a promise rather than an achievement." ${ }^{\prime 78}$

A week later, the Chinese consul, Shang Chi Su, argued his case in front of the City Club - of which both consuls were active participants ${ }^{79}$ - stating "I am going to indict the Japanese militarists at the bar of public opinion" for their "undeclared war on China." Shang stated that the root of the problem was the Japanese invasion of Manchuria on September 18, 1931, and the subsequent creation of the puppet state of Manchukuo, of which "China has always declared that she will never give such a recognition in violence of her sovereignty [in regards to official recognition of the country]." 80

These were the cases brought before the court of public opinion in Portland, where citizens were arguably keener than in the rest of the country (outside of

\footnotetext{
77 “Japanese Consul Reviews Far-Eastern Conflict,” The Portland City Club Bulletin 18, no. 29 (1937), 87-88.

78 ibid.

${ }^{79}$ They are referenced as members by the bulletins, but there is question as to their membership. 80 "Chinese Consul Condemns Japanese Aggression," The Portland City Club Bulletin 18, no. 30 (1937), 8990.
} 
Washington D.C.) to answer the question of the day, the Far East Problem. Japan had invaded Manchuria proper in 1931 and since that time hostilities between China and Japan had been ongoing. The rest of the world, and especially countries that had territorial (Britain, France, etc.) or economic interests in the area (the United States), wanted the situation resolved as soon as possible to keep the status quo. Exactly how to resolve the conflict while satisfying all invested parties (and of course the combatants) made up the Far East Problem. Formally, the United States made its statement by declining to recognize any new countries created by aggression in the Stimson Doctrine of January of $1932 .^{81}$ The prevailing belief-though phrased as neutrally as possible in the Stimson Doctrine and the following Lytton Report by the League of Nations - was that Japan was the aggressor and at fault. Despite this condemnation, the United States was unwilling to impose any economic sanctions against Japan, instead choosing to uphold the "Open Door" policy, which guaranteed equal access to trade with China for all. America's decision is possibly because President Hoover "adamantly opposed sanctions, which he dismissed as 'sticking pins in tigers."'82 Thus although America seemed ambivalent, it was very curious about the whole affair.

Due to its location as a west coast port city, Portland had developed a substantial population of both Chinese and Japanese immigrants, which led to consulates for both countries being established there by the turn of the century. Having consulates for both

\footnotetext{
81 "Stimson Doctrine, 1931." Stimson Doctrine, 1931 (January 2009): 72. Academic Search Premier, EBSCOhost (accessed May 10, 2014).

${ }^{82}$ George C. Herring, From colony to superpower: U.S. foreign relations since 1776 (New York: Oxford University Press, 2008).
} 
countries meant that Portland was a good example of an American city with vested interests in the East Asian Problem more so than much of the rest of the country. Between the criticism of Japan by the U.S. government in 1932 and the start of the war in 1941, Portland was a hub of discussion and activity surrounding the Far East Problem. Beyond touring foreign speakers stopping in Portland, there was considerable involvement between Portland and Japan during this period. From touting an Oregoneducated Japanese national with a powerful position in the government, Matsuoka Yosuke, to hosting a cadre of students from Tokyo to discuss peace, Portland's link to Japan persisted despite international tensions.

I will discuss the various aspects of the Far East Problem and how it was addressed in the Pacific Northwest generally, and Portland specifically. This is accomplished through an analysis of three separate forums of discussion: talks and lectures held for the public such as the City Club luncheons referenced above; newspaper columns and special features; and an examination of the pacifists from the Pacific Northwest. Through this analysis, I plan to shed further light on the complex scenario that arose in America in regards to the Far East Problem, and to investigate if the accepted belief that America wholeheartedly supported China stands true for a complicated situation like Portland.

\section{An Established Relationship}

Portland's historical position as one of the larger port cities on the West Coast placed it in prime position to be in significant contact with both Japan and China. Due to 
its location and size, Portland had a consulate for Imperial Japan and both Qing and subsequently Republican China. Asian immigrant populations in Portland were substantial for the size of the city, with the population of Asian-born people in 1880 around 9,500 out of the total population of 175,000 , or around 5.5\% of Oregon's total population. ${ }^{83}$ Even after the 1882 Exclusion Act which practically eliminated all immigration from China, immigrants from both countries still made up nearly $8.5 \%$ of Multnomah County's (i.e. Portland) total population of 103,000 , although they constituted a much lower $2.9 \%$ of the overall total state population in the 1900 census. ${ }^{84}$ However, Japanese immigrants had filled the void, and the Asian population of Portland in the 1900 census accounted for $10 \%$ of the entire city. ${ }^{85}$ At the turn of the century, the Chinese immigrant population in Portland had a higher concentration relative to total population than any other county in the United States by census data. By the early twentieth century, the Japanese and Chinese immigrant populations were established enough for business and community groups in both the religious and secular spheres to arise.

As elsewhere on America's western frontier, Chinese immigration to Oregon began as the result of a high demand for cheap labor in America and the massive population of economically disenfranchised people in Qing China. As early as the

\footnotetext{
83 "Historical Census Browser," University of Virginia Library, 2004, accessed November 20, 2014, http://mapserver.lib.virginia.edu/php/.

84 ibid.

${ }^{85}$ Campbell Gibson and Kay Jung, "Historical Census Statistics On Population Totals By Race, 1790 to 1990, and By Hispanic Origin, 1970 to 1990, For Large Cities And Other Urban Places In The United States" (Paper prepared for the U.S. Census Bureau, February 2005), 93, accessed November 12, 2015, https://www.census.gov/population/www/documentation/twps0076/twps0076.pdf.
} 
beginning of the 1850 s, Chinese immigrants were making their way up to Oregon after the dying gold rush in California led to the scapegoating of Chinese. At first, Oregon offered an ability to escape persecution while continuing the same work done in California without having to travel too far. Eventually, as had happened in California, the demand for cheap labor brought more Chinese to Oregon to do infrastructure work, particularly in the railroad industry. For example, in 1868 work on the Oregon Central Railroad began, and plans were announced to hire 1,000 Chine se workers. ${ }^{86}$ Beginning in that same year, after the signing of the Burlingame Treaty guaranteeing free movement between China and the United States, there were direct lines from Hong Kong to Portland loaded with more and more Chinese to work the railroads because of their lower cost compared to white workers. ${ }^{87}$ Other jobs for Chinese included mass production and industry jobs, such as mining, logging, and cannery work.

Though most Chinese were on their way out of Portland as soon as they arrived, some stayed to service those coming through. Thus, the Portland Chinatown was born. Chinese eventually found Oregon to be a safe haven from persecution in the 1870 s and 1880s. A prominent example is Moy Back Hin, a successful Chinese businessman and consul in Portland, who helped shelter and feed those Chinese forced out of Tacoma and California in 1885 , even going so far as to help with the cost of relocation. ${ }^{88}$ The support was not only from other Chinese; when the anti-Chinese movements that

\footnotetext{
${ }^{86}$ Nelson Chia-Chi Ho, Portland's Chinatown: The History of an Urban Ethnic District (Portland, Bureau of Planning, City of Portland, 1978), 7.

${ }^{87}$ ibid.

${ }^{88}$ Chinese Consolidated Benevolent Association, Ooligan Press, Dreams of the West; A history of the Chinese in Oregon 1850-1950, (Ooligan Press, Portland, 2007), 84.
} 
wished to kick out the Chinese finally spread to Portland in 1886, Portland's mayor John Gates and around 700 armed citizens formed a volunteer militia to protect the Chinese. $^{89}$

This is not to say that there were no racial tensions in Oregon. As is usually the case when people believe that foreigners are undercutting the local workforce, some Oregonians bore hostility against the Chinese. For example, an article in The Oregonian from 1864 opined that the Chinese were drains on society because they sent all of their earnings back to China and they were unwilling to change their "filthy" habits or assimilate to US culture. ${ }^{90}$ As a foreign labor force unwilling to assimilate to America and necessarily nomadic to follow the work, the Chinese were easy targets for ostracism. The impermanence of the Chinese bore a latent distrust of them early on, and the lack of Chinese females drastically slowed any permanent settlement. This lack of settlement meant the immigrant population was slow to bring a generation of American-born Chinese in before the national narrative had turned against them. ${ }^{91}$ Legal discrimination, such as not allowing Chinese to own land, implementation of the "Chinaman tax" in $1857^{92}$ in places like Jackson and Josephine Counties, and systematic limitations on property led to stymied growth for the Chinese in Oregon as it did elsewhere. Even though they were more accepted in Portland overall than in most places in America, the

\footnotetext{
${ }^{89}$ ibid, 10.

90 "The Chinese," The Morning Oregonian, June 21, 1864, 3.

${ }^{91}$ Chinese Consolidated Benevolent Association, Ooligan Press, Dreams of the West; A history of the Chinese in Oregon 1850-1950, (Ooligan Press, Portland, 2007), 24.

92 ibid, 84.
} 
Chinese were still victims of the national narrative against them; on the West Coast they were simply the favorite minority to blame.

Of course, interaction went both ways across the Pacific. For Pacific coast states, China presented an enticingly large market for trade. Having completed the transAmerican railroad lines in the early 1890s, the next logical step was the expansion of shipping trade from western ports like Portland in order to reach Asia. ${ }^{93}$ Forces from inside Oregon were pushing for the expansion as well, such as Theodore B. Wilcox, a flour and shipping magnate and owner of Portland Flour, the biggest exporter of wheat flour to China during the period. ${ }^{94}$ Wilcox was particularly keen for the facilitation of trade. It is partly due to the large amount of goods going to China from Portland Flour that "In 1889, the Union Pacific established a transpacific steamer line in Portland."95

The establishment of this infrastructure and the voices calling for more trade led to the adoption of the Open Door policy. The basis of the Open Door, established in 1899, was the agreement between China's major trade partners to allow equal access to Chinese trade and to maintain China's territorial borders. Though the Open Door appeared beneficial for the Chinese, the policy focused more on securing economic resources than on protecting Chinese sovereignty. Wilcox had established his Pacific empire by exploiting the underdeveloped flour markets in Asia, and knew that maintaining the empire required political involvement. It was to this end that he

\footnotetext{
93 ibid, 142.

${ }^{94}$ Daniel J. Meissner, "Theodore B. Wilcox: Captain of Industry and Magnate of the China Flour Trade, 1884-1918," Oregon Historical Quarterly 104 (2003): 532.

95 ibid, 535.
} 
championed John Barrett, an Oregonian who was commerce friendly and politically ambitious. Consequently, Barrett was posted as the U.S. minister to Siam. ${ }^{96}$ Barrett proved to be one of the leading voices calling for the creation of such a policy and pushing for more export of flour and timber to Asia. ${ }^{97}$ Wilcox and Barrett were two of the champions of expanding the Asian market in the U.S., and put Portland on the forefront of the opening of that door.

The opening of the Asian market for Portland led to the establishment of trade with Japan, which would eventually overtake China as early as 1896 and more than double that of China from 1912 until the war. ${ }^{98}$ Portland had been tapped as one of the first ports for major Japanese shipping companies as early as $1896 .{ }^{99}$ These steamer lines became an important vein of Japanese commerce, granting them the avenue to earn from the mass quantity of goods crossing the Pacific by importing to Japan and reselling to the rest of Asia. The trade was not one-sided either; Japanese shipping companies were also used for U.S. transactions with non-Asian countries, such as large shipments of lumber out of Portland. ${ }^{100}$ This direct link with Japanese shipping companies proved to be very beneficial, such as when it allowed the order of $\$ 150,000$

\footnotetext{
${ }^{96}$ Meissner, "Theodore B. Wilcox," 534.

${ }^{97}$ Salvatore Prisco, III, “John Barrett and Oregon Commercial Expansion 1889-1898," Oregon Historical Quarterly 71 (1970): 153.

98 "Exports, by country of destination: 1790-2001" in Historical Statistics of the United States, Millennial Edition On Line, edited by Susan B. Carter, Scott S. Gartner, et al., (Cambridge University Press, 2006).

99 "Another Japan Line Agents of The Toyo Kisen Kaisha Will Visit Portland," The Oregonian, July 24, 1896, 6.

100 "Lumber Going out. Cargo Purchased for Japanese Steamer Revives Interest," The Oregonian, October $17,1914,16$.
} 
worth of vehicles by Japan from a Portland company in $1919 .{ }^{101}$ The economic link only grew as time went on, with Portland alone exporting goods valued at $\$ 2,250,000$ to Japan in 1907 - more than $5 \%$ of the total US export to Japan-in mostly timber and foodstuffs. ${ }^{102}$

The increased economic interaction led to a more established Japanese immigrant presence in Oregon. The first Japanese immigrants began arriving in Portland in the 1880 s, and a consulate was founded in $1900 .{ }^{103}$ While at first Portland was not an overly desirable place for Japanese, the limitation of Chinese immigrants after the passage of the 1882 Exclusion act left a need for cheap labor. In Oregon, railroad contractor Shinzaburo Ban took advantage of the situation and grew his business by becoming the leading importer of Japanese labor during the late 1890 s. He used this as a base to launch his prominent mercantile shop in Portland and open a lumber mill near Linnton, which made him the wealthiest Japanese businessman in the state by $1900 .^{104}$ Ban's success meant that by the turn of the century Portland was the main port of entry for Japanese railway workers in the Pacific Northwest, which led to more Japanese immigrants filling Chinese vacancies in the lumber, cannery, and menial labor markets. The increase in immigrants flowing through Portland consequently led to the

\footnotetext{
101 "Portland To Send Trucks To Orient Northwest Auto Company Contract With Japanese. \$150,000 Total Involved," The Oregonian, December 14, 1919, 70.

102 "Commerce with Japan," The Oregonian, October 10, 1912, 8.

103 "Japan Oregon Relations," accessed November 29, 2014, http://www.portland.us.embjapan.go.jp/tips/Japan-Oregon\%20Relations\%EF\%BC\%882014\%2006\%EF\%BC\%89.pdf.

${ }^{104}$ Barbara Yasui, “The Nikkei in Oregon, 1834-1940," Oregon Historical Quarterly 76 (1975) 229.
} 
establishment of Japanese-run businesses and social establishments in the between the 1890s and early 1900s. ${ }^{105}$

With help from Ban, the establishment of the Japanese Methodist Mission in 1893 became a central aspect of Japanese culture in Portland. It is at this mission that Yosuke Matsuoka first established residency in Portland. ${ }^{106}$ Matsuoka eventually found his way to the University of Oregon, where he graduated from the law school by taking night classes while working during the day for Ban. ${ }^{107}$ After graduating, he was briefly employed by Ban. Historian Masaharu Ano describes Matsuoka as Ban's "right hand man."108 Matsuoka later returned to Tokyo to further his studies. Though his reputation would later turn infamous, Matsuoka is a prime example of the rapid rise in Japanese presence in Oregon facilitated by earlier economic investments.

Just as with the Chinese, Japanese prosperity in Oregon brought resentment from Caucasians. In places where the Japanese immigrant population flourished in agriculture, such as Hood River (east of Portland along the Columbia River), groups began forming to officially oppose the Japanese presence. ${ }^{109}$ The same racist assertions that were employed against the Chinese - that they would not assimilate - were brought back by farmers afraid of Japanese invasion of land. ${ }^{110}$ In response to the increased Japanese immigration, the Alien Land Law was passed in 1923. This law

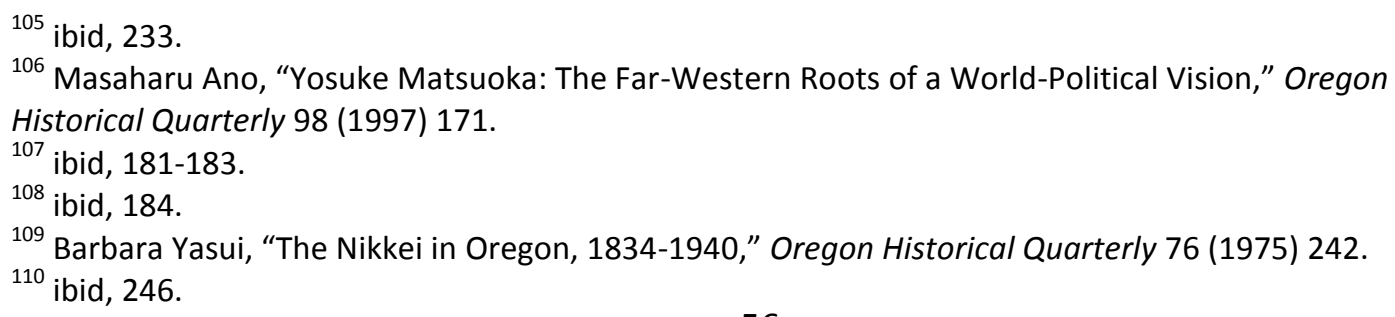


prevented Japanese and Chinese immigrants from purchasing land in Oregon. ${ }^{111}$ The law quelled fears of a 'Yellow Invasion' in Oregon and mostly put the brake on growth in the two communities. ${ }^{112}$ The law effectively put a cap on the era of mass immigration and influence, and essentially set the stage for the debates on Asian affairs in the coming years. By the time the law passed in 1923, the Asian population in Portland had already dropped by about $60 \%$ from its 1900 high, to $3,675 .{ }^{113}$ The law must have been effective, since the Asian population in Portland, and indeed the state, stagnated for the next 30 years. $^{114}$

Because of the lateness of Japan's arrival and the fact that Japanese immigration had only recently been curtailed, it is easy to see how sympathies toward Japan would be higher solely due to recency. More than that, Japanese immigrants had gone a long way in the process of assimilating to American culture in the short time they were allowed, and had immigrated in an era when it was much easier for businesses to prosper. When combined, these aspects left the Japanese in a better light than the Chinese at the time of rising tensions in Asia.

\section{The Portland City Club}

\footnotetext{
111 “1923 Alien Exclusion Law," accessed November 29, 2014, http://www.ccrh.org/comm/slough/primary/general.htm.

112 Barbara Yasui, “The Nikkei in Oregon, 1834-1940," Oregon Historical Quarterly 76 (1975) 247.

113 Unfortunately, the Census had changed the question on birthplace from a few individual Asian countries to just "Asia." Therefore, only the total number of Asians in Portland is available. The increase in Japanese activity, however, indicates that by 1920, the majority of Asians in Portland were Japanese.

${ }^{114}$ Campbell Gibson and Kay Jung, "Historical Census Statistics On Population Totals By Race, 1790 to 1990 , and By Hispanic Origin, 1970 to 1990, For Large Cities And Other Urban Places In The United States" (Paper prepared for the U.S. Census Bureau, February 2005), 93, accessed November 12, 2015, https://www.census.gov/population/www/documentation/twps0076/twps0076.pdf.
} 
The precedent of economic interactions between Asia and Oregon made the Far East Problem a prominent one for the Portland City Club. The City Club was a group of civic-minded businessmen for the purpose of discussing the growth and future of Portland. They numbered around five hundred influential Portland men by 1931, and remained at about the same number during the following years. ${ }^{115}$ Early on in the Far East conflicts, the club began hearing prominent speakers on the subject. The presence of these speakers and the discussions they inspired alone tell us that there was substantial interest by the business class and civic leaders that made up the City Club in resolving the Far East Problem. It also speaks to the club's inclination on the matter that the discussions focused mainly on how to attain peace and return to the status quo rather than the decrying of Japanese aggression.

As early as January 1933, the City Club held a luncheon hosting Dr. Inazo Nitobe, a famous Japanese-born and U.S. educated author, once Under-Secretary General of the League of Nations, and a prominent Christian. Though Nitobe was a prolific author and orator who spoke frequently, his presence in Portland should not be overlooked as his opinion on the matter was highly regarded. Nitobe had gained fame as an anti-militarist member of parliament in Japan and for his exceptional English. His book Bushido: The Soul of Japan, published in 1900, was the first work written for Western audiences on the topic of samurai ethics and Japanese culture, and it became very popular. The popularity resulted in the book becoming the basis for the popular understanding of the

${ }^{115}$ Lucia, Ellis. The Conscience of a City; Fifty Years of City Club Service in Portland, the City Club of Portland Golden Anniversary, 1916-1966 (Portland: The City Club of Portland, 1966), 33. Accessed at http://www.pdxcityclub.org/Files/Conscience\%20of\%20a\%20City.pdf. 
modern Japanese national identity in the West. ${ }^{116}$ It is at this speech that, though he had his own issues with militarism in Japan, Nitobe made the claim that "Japan does not desire war with the United States."117 The presence of such a renowned expert on Japanese identity and noted anti-militarist stopping in Portland on his tour of the West Coast to assuage fears of Japanese aggression ${ }^{118}$ shows that Portland's business class was not only involved in the discussion, but that the economic side of the city was willing to hear Japan's case rather than immediately judge it.

Shortly afterward, a string of Americans spoke in front of the City Club with updates on the situation and how it affected America. Dr. J. Leighton Stuart, president of Yenching University in Peiping (Beijing), an advocate for Nationalist China, and later witness to the Nanking Massacre, spoke to the Club in March of 1933 to state that the path to peace was to strengthen democratic China, both decrying Japan's militarism and admitting China's weakness. ${ }^{119}$ Dr. Stuart either played to the crowd or honestly believed that there was nothing to be done about the Japanese aggression, but that it was instead part of their nature (their "war psychology"120) and the only solution was then to build China up so much they would no longer be a target. In September of the same year, William E. Hocking continued Stewart's point by assuring the Club that China's education system was thriving from the bottom up, unlike the militaristic top-

\footnotetext{
${ }^{116}$ Hurst III, G. Cameron. "Death, honor, and loyalty: The bushido ideal." Philosophy East \& West 40, no. 4 (October 1990): 511.

117 "America and Japan," The Portland City Club Bulletin 13, no .36 (1933): 1.

${ }^{118}$ Hurst III, G. Cameron. "Death, honor, and loyalty: The bushido ideal," 511.

119 "Strengthen China and Remove Manchurian Difficulties Says Speaker," The Portland City Club Bulletin 13, no. 46 (1933): 1.

${ }^{120}$ ibid. 
down approach of the Japanese. He further attempted to assuage the fears of the Club by downplaying any influence the Soviets had on the Chinese and implied that China was ripe for growth if the US would work with them. ${ }^{121}$

Dr. Elmer A. Fridell, pastor of the First Baptist Church of Seattle, spoke in December of the same year. After having returned from a tour of the Far East, Dr. Fridell claimed the Japanese industry wanted peace and that the Japanese government was harming their own economy from markets closing against their militarism. ${ }^{122}$ Judging from the speakers who visited the Portland City Club, the consensus in 1933 was that the military was out of control, but that overall Japanese growth should not -or could not - be stopped and that the best solution was to work around the militarists by securing that growth diplomatically. The Japanese economic growth that Oregon benefitted from was likely responsible for this non-interventionist view.

Though these first discussions focused on Japanese sovereignty and peace, the discussion began to change in 1934 after hostilities showed no signs of slowing. Discussions soon focused on the economic implications, military possibilities, and issues with the global relationships that contributed to the problem. One outlook was that of the trade commissioner in Tokyo for the U.S. Bureau of Commerce, who spoke to the Club in July of 1934. The commissioner marveled at Japan's economic growth and speculated that U.S. trade with Japan would become increasingly important for the

121 “China's Future Promising Says Hocking," The Portland City Club Bulletin 14, no. 21 (1933): 1.

122 “Japanese Industry Wants Peace Says Dr. Fridell," The Portland City Club Bulletin 14, no. 31 (1933): 2. 60 
future of both countries. ${ }^{123}$ Realistically, trade was what most of the City Club's members were interested in because of the promise of growth in Portland.

The lengthening conflict also brought worries of war, which was discussed by Major R. S. Bratton in November of 1934. Bratton warned of a Japan victorious over China with a unified and advanced army fed by China's vast resources. ${ }^{124}$ Dr. T.Z. Koo, a vice-chairman of the World Student Christian Federation, leader of the Chinese Y.M.C.A, and onetime diplomat, took a different view on the military. Unlike Brattan - who being a military man would be inclined to such things - Koo discussed with the Club a scenario of peace that no longer demonized Japan by instead choosing to frame the situation as two developing nations that were in conflict with each other. ${ }^{125}$ Koo believed that they should instead be uniting against the greater threat of Soviet ideology by "creating an Asiatic bloc to oppose Russia." ${ }^{126}$ By framing Japan and China as on the same side ideologically compared to the Soviets, Koo manages to avoid victimizing or demonizing either side. The opposing views of the war led to the question of whether Japanese aggression was something to be feared, or something that would help resist Russian/Soviet ideological spread.

Finally in 1936, the Japanese Consul in Portland, Ken Tsurumi, discussed with the Club the possibility that the foundation of this problem did not lay in the issues between China and Japan, but that the Eurocentric treaties were inadequate to deal with Asia.

\footnotetext{
123 "Trade Commissioner From Tokyo Speaks," The Portland City Club Bulletin 15, no. 10 (1934): 2.

124 Portland City Club Bulletin 15, no. 30 (1934).

125 Development of Peace Pacts Declared Need in Pacific," Portland City Club Bulletin, 16, no. 12 (1935).

${ }^{126}$ Campbell Gibson and Kay Jung, "Historical Census Statistics On Population Totals By Race," 93.
} 
First, Tsurumi asks the heavier questions such as "what is China without a stable government?" and “is Manchuria part of China?"127 He argued that Japan's special relationship with China was based on respect for the origins of its culture and the centuries of interaction meant Japan would be much better suited to aid in the "rehabilitation and unification" of China. ${ }^{128}$ The consul believed that if Japan and the rest of Asia were to work out their own agreements on a separate scale from the League of Nations, America's Open Door policy would be secured while at the same time these countries would be allowed to climb the global hierarchy. This idea would likely have sounded appealing for an America that wanted the most economic benefit with the least amount of direct intervention.

The City Club's meetings and the guests they heard provide a valuable insight to the perception of the Far East Problem in Portland. These discussions indicate that the business and middle classes in Portland were unwilling to discard the relationship with Japan over some international aggression and instead were looking for a way to return peace and economic stability to the area. The means to achieve this peace included simply defeating Japanese militarism, a modification of Chinese and Japanese relations, and eventually a discussion of the position of Asia in the hierarchy of nations. Unfortunately, like most civic clubs, the City Club was much more adept at discussing solutions than acting on them, and nothing concrete came from these talks. Still, the

127 "Peace and Order in Asia Declared Vital," Portland City Club Bulletin, 17, no. 15 (1936), 2. 128 ibid. 
fact that the club was hosting these speakers and focusing on these problems alone implies the interest present in Portland for a solution.

Both Japan and China had been trying to climb the hierarchy using western rules since their respective civil wars, but upon rising in the ranks, they discovered that exclusion and racism kept them out of the top tier. Both countries wanted to continue dealing with the global economy (China for support and Japan for goods), but Japan proposed doing so on a new platform decided by Asian countries, with Japan, as the most advanced, at the head. The unifying theme of all of these talks was that the path which most benefits America is the best path for Asia, and Japan's offer was a promise to be both the best economically and the least amount of effort.

\section{The America-Japan Student Conference}

Discussions at Portland's Reed College revolved around this point during the Second America-Japan Student Conference in July and August of 1935. The stated purpose of the conference was "intimate and frank round table discussions of those seeming points of conflict between the two nations."129 The specific agenda of this conference, the first official one in America (the first was in Tokyo), was to discuss the rise in naval tensions, trade, and land interest between the two countries. ${ }^{130}$ As the forward to the official companion pamphlet makes very clear, this conference was set

\footnotetext{
129 "The second America-Japan Student Conference, 1935," Introduction, The Second America-Japan Student Conference Papers, Portland OR, Reed College Libraries, Archives Department (hereafter cited as AJSC Papers).

${ }^{130}$ Ibid.
} 
up entirely by students from both countries in an attempt to bridge the gap between the two countries and open an avenue for Japanese and American youths to speak about international problems and the future of their countries. In their efforts to do so, they attracted many influential participants such as noted academics and politicians from across the country. ${ }^{131}$ However, the bulk of the presentations and discussions were by the students from both delegations. The choice to have the conference at Reed was due not only to the enthusiasm of the school and its benefactors, but because Portland's attitude toward the Japanese ensured a constructive discussion.

The format of the student conference was based around professional lectures and round table discussions on selected topics. Some of the students and speakers at the conference were refreshingly objective when discussing relations between their countries. For example, Victor A. Morris from the University of Oregon spoke on trade relations, and noted that obstacles to the relationship included "intense nationalism, racial prejudice and the American worship of the high protective tariff." ${ }^{132}$ By bringing in to question American actions which were largely accepted as a fact of life in the national discussion, the student implicitly agreed with the Japanese belief of reduced American political pressure in Asia. One Dr. Letourette from Yale University bought fully in to the conference's goal by proposing an increased cultural interaction between Japan and America as a means to avoid war. ${ }^{133}$

\footnotetext{
${ }^{131}$ One notable attendee was the son of one of Japan's top generals, for example.

132 "The second America-Japan Student Conference, 1935," Pg. 19, AJSC Papers.

133 Ibid, 24.
} 
Discussions of the future from Westerners at the conference focused as much as possible on the development of a better international relationship, yet at the cost of discussing Japanese militarism; not once was the cessation of hostilities toward China brought up as an option for peace. This omission could be due to tact the American hosts exhibited toward their guests, or it could be a show of Portland's trust of the Japanese by choosing to focus on the future rather than the present and recent past. Whatever the reasons for the omission, the fact remains that a prominent American professor (from Yale nonetheless) spoke in a forgiving manner in regards to Japanese aggression.

The speakers from Japan also focused on the future, but discussed Japanese imperialism in a different manner. While agreeing that racism was keeping Japan from being recognized as an equal by the other "Great Powers," Dr. Yamato Ichihashi from Stanford issued the challenge "Manchukuo is here to stay whether the West likes it or not."134 This sentiment, similar to Inazo Nitobe's message to the City Club in 1933, was an intriguing tactic to try and convince Americans of Japanese global presence. Dr. Ichihashi spoke of Japan's relations as inevitable in order to relate to the similar belief that America's prominent international role was assumed, despite many Americans feeling insular. Due to the limitations of the conference format, the future of China was only discussed as a part of Japanese sovereignty and imperialism.

134 Ibid, 23. 
The permanence of Japan's global position was the base of these arguments from the Japanese speakers. By treating Japan's rights in Asia as assumed, supporters of Japan could argue based on the status quo established by Western nations in Asia during the nineteenth century. This tactic of forced normalcy was the process employed by the American nation as it expanded westward, and it is what the Japanese hoped to achieve in Asia. Japanese advocates then used this idea to play to American concepts of expansion and control. To that end, another speaker from Japan pleaded with America, by proxy of those in attendance, to understand that "this is a dynamic world, and that boundaries of nations cannot remain static." ${ }^{135}$ In addition to these statements of change, the Japanese speakers and students all preached the idea that what Japan was really struggling for was stability, both economically and politically. Japan was trying to accomplish that stability via forceful means in China. Were Japan's actions really any different than American expansion?

One thing that the conference's attendees seemed to agree upon was that Japan's problems were economic in nature, and that the League of Nations was failing to bring any economic securities. One critical cause was what one speaker, Dr. Linden A. Mander of the University of Washington, claimed as a lack of sincerity by the great powers toward the League ideal. ${ }^{136} \mathrm{~A}$ Japanese student speaking on the subject called the League "at present [...] a league of European nations," and claimed the Japanese

\footnotetext{
${ }^{135} \mathrm{Ibid}, 14$.

${ }^{136} \mathrm{Ibid}, 36$.
} 
would like to see a regional league set up in Asia. ${ }^{137}$ A student from Reed College declared that "Japan suffers from the chaotic condition of Asia. Therefore the world should allow Japan to put things in order." ${ }^{138}$ At the time, criticism of the League was by no means limited to Japanese affairs. America was not part of the League and the belief that it was a good concept with a flawed execution was growing globally. However, the idea of an Asian version of the League dominated by a benevolent Japanese influence being so supported at this conference shows a uniquely high regard for the competence of the Japanese government. The final portion of the conference was dedicated to round-table discussions of the similarities and differences between Japanese and American political systems. Even here, the discussion was focused more on comparing the values of political approaches rather than accusatory of Japanese focus on military.

The conference holds special significance in the discussion surrounding Japan in the 1930s due to not only its content but its existence at all. The occurrence of the conference speaks out to two points: the cleverness of Japanese international planning and the willingness of Oregonians to receive the message Japan was sending. The discussions at the conference showed a movement of Japanese intellectual youth yearning for international acceptance and a sympathetic group of Oregonians willing to admit that world organization was flawed. Most importantly, this conference shows a group of Americans willing to see past the troubles that Japan was having to a better future which could be created through cooperation rather than threat of military or

\footnotetext{
${ }^{137}$ Ibid.

${ }^{138}$ Ibid, 38.
} 
economic action. This conference is possibly the most earnest example of hope to work with Japan as a whole instead of paid shills making excuses for imperialism. The earnest drive for peace and further understanding was similar to the motives and beliefs of many American pacifists.

\section{The Oregonian}

The most visible way to interpret community reactions to a certain event in the first half of the twentieth century is to read the newspapers. The Oregonian (alternatively titled The Morning Oregonian), published in Portland, is one of the oldest continually published newspapers in the Pacific Northwest, and has always been the largest paper for the region. ${ }^{139}$ Therefore, one can gauge the interest in the Far East Problem as well as Japanese and Chinese relations by reading what the people of the time would have read. Like other forms of popular opinion, the initial response to Japanese aggression in the news was harsh and directed mostly at the militarists, but became measured and more thoughtful once the possibility of the situation being permanent became a reality.

In a small bit of commentary at the end of a 1932 article describing the Japanese pre-defense to the impending Lytton report, The Oregonian made the following complex statement: "[The military party] could not have gained and held power unless the Japanese people considered its policy necessary to national safety. The instinct of

\footnotetext{
139 "A Brief History of Newspaper Publishing in Oregon," accessed May 31, 2014, http://library.uoregon.edu/govdocs/indexing/newspaperhistory.html.
} 
national self-preservation dictates Japanese policy" and that the movement in China is the only defense against Russia. The article concludes with the statement that "Eastern Asia seems destined to be dominated by either the Soviet Union or Japan." ${ }^{140}$ Though admitting the antagonism of the militarists, the article explicitly asked the reader what else the Japanese could have done, since China was bound to be dominated by one country or another. In contrast, another report from the same period by the Asian specialist Pat McGrady describes the militarists less favorably, stating that they are not only imperialistically driven but economically irresponsible, willing to ruin the economy to satiate a lust for conquest. ${ }^{141}$

The opinion of the paper became complicated rather quickly. In March of 1933 The Oregonian published a front page (below the fold, but still) story on the new celebrity and importance of onetime Oregonian Yosuke Matsuoka. Extolling his virtues and skills as a diplomat, the article not-so-humbly implies that the successes are related to his Christian upbringing and schooling in Portland and at the University of Oregon. ${ }^{142}$ In the same article, the authors brag that "he is said to be the best-informed man in his country on Manchuria." ${ }^{143}$ Refraining from making a single commentary on Japanese militarism or aggression, and instead choosing to highlight a successful Japanese diplomat with Oregonian training, is emblematic of the trepidations the public in Oregon had toward immediately demonizing the Japanese, even while the American

\footnotetext{
140 "Japan Still Defiant and Why." The Oregonian, August 27, 1932, 4.

141 Pat McGrady, "Far East Listens to America's Word," The Oregonian, March 1, 1933, 14.

142 David W. Hazen, "Matsuoka, Japan's Noted Statesman, Once Peddled Coffee in Portland," The Oregonian, March 26, 1933, 1, 7.

143 Ibid, 7.
} 
government was doing so officially and Matsuoka had just shocked the world by walking out of the League of Nations.

As time went on, the opinions on Matsuoka and his political career became more complicated. When the diplomat made a trip to Washington D.C. to speak to the president in April of 1933, he stopped over in Oregon on his way back to Japan to make a speech at the University of Oregon. On the day of his arrival, The Oregonian warmly welcomed Matsuoka, commenting that he had been "more than loyal" to his Oregon upbringing and that in turn "Oregon would receive him with a loyalty equal to his own." ${ }^{144}$ The article even comes to the defense of Matsuoka's boldness, claiming that it is the American part of him that causes this by calling it "a product of the University of Oregon rather than the University of Tokio [sic]."145

When the story of Matsuoka's visit and speech ran a few days later, the paper acknowledged the controversy surrounding Mr. Matsuoka and his actions on behalf of Japan more openly, but also allowed his comments on the matter to stand without commentary. ${ }^{146}$ Frequently, the questions asked of Matsuoka focused on JapaneseAmerican tensions, and Matsuoka's responses were sometimes testy: when asked if the Japanese would give up the islands in the Pacific it took control of after Germany's defeat in World War I, he responded "do you want them?"147 However, the article still took the time to comment on how well received Matsuoka was by both Japanese-

\footnotetext{
144 “Greetings to Mr. Matsuoka," The Oregonian, April 7, 1933, 6.

145 ibid.

146 "Matsuoka Wary of Naval Splurge," The Oregonian, April 8, 1933, 1, 14.

147 ibid, 14.
} 
Americans and all the Oregonian associations he visited. The subject of Matsuoka's speech at the University of Oregon law school was the lack of and need for stability in China, where after playing up the internal chaos of China he was asked what Japan was going to do about it. To this question, Matsuoka questioned the willingness of America to do anything about it while simultaneously assuring the audience that Japan could not do anything besides try to keep peace in the corner of China it had influence over, Manchuria. ${ }^{148}$

It is important to note that the article on this controversial global figure ended with the statement that the "theme of eventual peace" ${ }^{149}$ ran throughout Matsuoka's visit, and that the last article to run before he returned to Japan was a humanizing piece about his dedication to his departed Portland benefactress. ${ }^{150}$ The treatment of the controversial figure of Yosuke Matsuoka by The Oregonian is indicative of the mixed feelings toward Japanese aggression at the time in Oregon. The pride felt by Oregonians in Matsuoka gave them more reason to contemplate both sides of the Far East Problem than the rest of America.

The mixed feelings only continue in 1934. In a piece by Fred W. Vincent, Japan's militarist government was said to be "committed to a program of conquest in defiance of world opinion." ${ }^{151}$ The article is unique in its choice to separate the hard working core

\footnotetext{
${ }^{148}$ ibid.

149 ibid.

150 "Matsuoka Honors Boyhood Friend," The Sunday Oregonian, April 10, 1933, 1.

${ }^{151}$ Fred W. Vincent, "Why Japan Rattles the Sabre," The Sunday Oregonian, June 3, 1934, Magazine Section pg 1. 
of the Japanese people (photos of which litter the article's pages in traditional garb with helpful captions describing the tradition) from the incompetent management by the militarists, and declared the economic situation unsustainable. ${ }^{152}$ Yet, a little over a month later, The Oregonian informed readers that a Japanese training ship, the Taisei Maru, would dock in Portland and its cadets feted and given various forms of entertainment. ${ }^{153}$ If that were not enough of a contradiction of the distrust of Japanese militarists, the article also mentions that "the ship will be open for inspection by the public on two or three afternoons of her stay here." ${ }^{154}$ Apparently, appreciation of Japanese sailing training and technology, which almost certainly had a part in supporting the war effort, was not incompatible with condemnation of Japanese militarists!

Just like the speakers to the City Club, The Oregonian shows a city becoming more accepting of Japanese aggression over time rather than less. For example, the reporting on the America-Japan Student Conference could not have been more positive and hopeful, with statements like "the understanding that such an interchange of culture between the young folk of the two countries brings about eventually will result in a new renaissance of internationalism." ${ }^{155}$ Slightly more than a year later, the paper reported on two prominent Oregonian activists who went to Japan to deliver a medallion to Matsuoka and were attended to fantastically. ${ }^{156}$ The article mentions nothing negative and seems to celebrate the connection with Japan. In that same vein, a

\footnotetext{
152 Ibid.

153 “Japanese Cadets Will be Welcomed," The Oregonian, July 17, 1934, 12.

154 Ibid.

155 "Japanese Praise Oregon Scenery," The Oregonian, August 1, 1935, 4.

156 "High Officials Genuine Hosts," The Oregonian, September 25, 1936, 24.
} 
visit from the Japanese Ambassador was deemed noteworthy in a positive manner as late as 1939. While issues with China were brought up, the ambassador's calming answers were left to stand on their own. The article even ended stating that the dinner in the ambassador's honor was attended by almost every influential person in Portland, and only missed by the governor due to scheduling issues. ${ }^{157}$

The analysis of these news articles is telling of public opinion at the time. If one were to follow the accepted narrative of decreasing trust for Japan and increasing support of China by America, it is not so easily found in The Oregonian. In fact, quite the opposite occurs. The Japanese were treated more favorably as time goes on rather than the opposite. Either due to standing connections (such as the pride in Matsuoka), diplomatic ties, or economic interest, The Oregonian portrays a much more hopeful narrative for Japan than the American historical memory perceives. The underlying theme of all of these articles, from support of the diplomat to criticism of the militarists and their economic sense, is that there is some greater value in Japan and the Japanese people, only that it is being shadowed by war. Ultimately, however, news can be much sparser than one would like when searching for opinion. It is best to find direct opinions on the matter, which, thankfully, there were some from the Pacific Northwest that had strong opinions on the matter.

\section{The National Council for the Prevention of War - Portland Branch}

\footnotetext{
${ }^{157}$ David W. Hazen, “Envoy of Japan Welcomed Here," The Oregonian, May 4, 1939, 10.
} 
The National Council for the Prevention of War (NCPW) was a lobbying group based in Washington D.C. that was founded in 1931 with five branch offices across the country, one of which was in Portland. ${ }^{158}$ The fact that a branch was located in Portland, which was very active in scheduling lectures and publishing anti-war material, shows that the discussion in Portland was robust enough to require attention from the organization. From scheduling documents, it appears that this branch was most active in fostering anti-war opinions amongst the general populace by speaking at churches, schools, and business groups such as the City Club. ${ }^{159}$ The goal of the organization was the reduction of arms worldwide and the maintenance of peace through diplomacy. It is in this last effort that the NCPW sent their associate secretary J.J. Handsaker, head of the Portland office, and Dr. E. Guy Talbott on a tour of Japan, Manchukuo, and China in 1935 at the invite of the Japanese government. The trip would be reported to the head of the council and lobbied in Washington D.C. Though his motives for this trip absolutely color the commentary that followed, Handsaker's opinion still exemplifies the Oregonian view of the East Asia Problem.

Handsaker logged his journey by writing letters to the NCPW main office throughout the trip. On the steamer ship to Japan, he thought it interesting to point out that while studying the situation he came upon a passage from a recent book by the president of the University of Hawai'i stating that the Chinese should welcome Japanese capital and development strategy of Manchuria because they were previously unable to

158 “Historical Information," accessed June 3, 2014, http://www.swarthmore.edu/library/peace/DG001025/dg023NCPW/Historicallntroduction.htm.

${ }^{159}$ I was, unfortunately, unable to find the Bulletin for this. 
develop it themselves, and that in the end "no nation can really conquer China, for in the end this latent power will engulf the would-be conqueror." ${ }^{160}$ The fact that Handsaker felt this worthy of note tells the reader of the precedent of international relations built on economic development, and of the belief of eventual security of China based on sinicization. Once he arrived in Tokyo in August, Handsaker wrote of the Japanese that "we have found a settled conviction that international circumstances have made Japan the guarantor of order and security in the Far East" and "to be perfectly frank, up to this time, we have found no more jingoism, and no more evidence of militarism, than we have in the United States." ${ }^{161}$ First, it is noteworthy that Handsaker clarifies that he believes the Japanese motives are well-intentioned. Even if he was just trying to soften the blow of coming criticism, the fact that he felt it necessary to do so testifies to the sentiment for the Japanese back home. Also, even when specifically on the hunt for it, Mr. Handsaker comments on the surprising lack of militarism in Japan.

While in Japan, Handsaker appears to have been thoroughly impressed with the country, but the opinions of both Handsaker and Talbott shifted when they visited Manchukuo and China. In a letter from China in September 1935, Talbott writes to Frederick J. Libby, an executive of the NCPW, that "Manchukuo, at present, is completely dominated by the Japanese Kwantung Army, and is in no true sense an

\footnotetext{
160 J. J. Handsaker to NCPW, July 19, 1935, National Council for the Prevention of War Papers, Swarthmore Peace Archives, Swarthmore College, Box 125, mf reel 41:112.

161 J. J. Handsaker to NCPW, August 5, 1935, NCPW Papers.
} 
'independent state."'162 Handsaker adds to the discussion by stating that the Chinese with whom he spoke despaired at their situation under the Japanese, but were just as disenchanted with their own country's ability to unify as they were upset by Japanese control. ${ }^{163}$ Handsaker of course also includes that those same people he spoke to did not believe that American military intervention would resolve the situation.

Before he returned, Handsaker wrote of several concluding thoughts about the Far East Problem. First among these observations is "that Japan's real need for markets, raw materials, and a place for her surplus population should be the subject of international action in the light of all the factors concerned." ${ }^{164}$ However, Handsaker argued with Japan's chosen method of solving that problem, stating "that Japan's effort to solve her problems by the setting up of the Manchukuo government and by her invasion of North China is opposed by many Japanese who are not able, openly, to express their disapproval." ${ }^{\prime 165} \mathrm{He}$ also describes China as a country on the rise, and the cause of the friction between the two countries is based in the overlapping areas of resources needed to continue the growth of both countries. Perhaps due to Handaker's position as a peacekeeper he presents the Far East Problem as neutrally as possible by describing issues of Chinese division and Japanese militarism as only obstacles of peace rather than indications of deeper problems.

\footnotetext{
${ }^{162}$ E. Guy Talbott to Frederick J. Libby, September 10, 1935, NCPW Papers.

163 “Report Letter \#3," J. J. Handsaker to NCPW, September 19, 1935, NCPW Papers.

164 “Report Letter \#3," J. J. Handsaker to NCPW, September 19, 1935, NCPW Papers. 165 ibid.
} 
When discussing Japanese militarism, Handsaker speaks in chorus with earlier voices from the City Club, stating that many see a distinct division between "Kwantung army operating in Manchoukuo and North China and the Japanese government in Tokyo." ${ }^{166}$ After laying the blame for the tensions on the rogue military, Handsaker states that China would be unable to forge a proper resistance to Japan, and even if China could, "that resistance would probably mean a world war." ${ }^{167}$ To disarm the military tensions, Handsaker-who placed America in the same economic sphere of interests in the area as China, the Soviet Union, and Japan (countries that are actually in the area)-suggested that the Exclusion Act limiting Oriental immigration to the U.S. be immediately repealed and that the American bluff of expanding the navy to intimidate Japan was instead causing an arms race that hindered peace. ${ }^{168}$

What does this trip tell us, other than that Mr. Handsaker was quite an astute observer? It shows the persistence of the belief that the Far East Problem could still have been solved by economic and diplomatic measures. Handsaker was of course tainted by his position, but his obvious appreciation for the Japanese people, if not the militarists running the Kwantung Army, was emblematic of the overall Oregonian connection to Japan. The obvious distinction, especially compared with opinions toward Nazi Germany at the time, is that the Japanese are not considered bad per se, just that they have made a mistake that can be corrected, and that the situation in Asia leading to the Far East Problem is not due to Japanese aggression, but the cause of it. Much like ${ }^{166}$ ibid.
${ }^{167}$ ibid.
${ }^{168}$ Ibid. 
the other examples cited here, Handsaker's solution to the problem revolved around a higher international respect for Asian autonomy and a call for the American government to stop exacerbating the situation through exclusionary policies.

\section{The Kindred Souls of the Pacific}

Oregon played a distinctive role in the years leading up to World War Two. The evidence discussed here shows that the Far East Problem was not just viewed as a question of unified Japanese aggression to Oregonians, but was instead portrayed closer to the complex question of responsibility and power in East Asia that we understand now. The familiarity that Oregonians had with both Japan and China due to a history of interactions with both countries led to a deeper investigation of the causes and solutions for the conflict than most Americans would be equipped to discuss. The responses presented in public forums such as the Portland City Club and The Oregonian varied from blaming the Chinese, the militarists, the global economy, Western influence, and American policy to thoughts of redefining the globe to accommodate Japan's growing empire. The underlying theme in Portland, especially represented by the American-Japan Student Conference, is that Oregonians were willing to consider many possibilities which did not demonize the Japanese society or people as a whole. Instead, when criticism was brought at all, it was either against Japanese militarism specifically or the system which brought about such a situation. Oregonians were willing to believe that the Japanese and Americans could solve this problem throughout the entire 1930s. Whether that solution meant returning to the paradigm before the aggression in China 
by offering other solutions for Japanese growth or forging a new paradigm that reconsidered the idea of East Asian autonomy, Oregonians were certain that the Japanese were allies, not enemies.

Most importantly, Oregonians believed that the key to solving all of these problems was to interact directly with the Japanese. From bringing Japanese intellectuals and Asian specialists to speak, to inviting an entire delegation to discuss the future, Portland was a hub of discussion between the Japanese and Americans on the West coast. Portland's role is further exemplified by the NCPW sending a delegate from the Portland office to tour the Japanese empire and give an honest opinion of the situation. Outside of the economic and diplomatic spheres, the personal relationships with Japan as exemplified by Matsuoka's strong connection to Oregon solidified the link between the two and led to a more in-depth discussion of the Far East Problem than one would expect of such a small city. The particular situation in Portland makes it an excellent case study in popular Japanese-American relations at the time, which shows that, in places, the two cultures were far more willing to work with each other than the American popular memory believes. These are the reasons why Portland is the ideal point for discussing the comparison of threats to the United States before the war. 


\section{Chapter 3 - The Rising Sun or the Soviet Star}

An integral piece of the Far East Question in Portland that must be investigated further was the claim that China was being overrun by Communists. By the 1930s, the Pacific Northwest had long since been known as a bastion of labor and union power. Historically, in the Pacific Northwest, a small population had been dispersed over a large area whose industries were for the most part limited to natural resources. The largest industries included forestry, canning, and shipping - all of which were, if not unionaffiliated, at least labor-friendly. Though much of the organized socialist and labor activity were focused in Washington at the turn of the twentieth century, the rural areas of the entire Pacific Northwest were friendlier to socialist politics, as can be evidenced by Socialist presidential candidate Eugene V. Debs' multiple tours of the area in 1908. However, at that time Portland was a different world than the surrounding rural areas. While pro-labor forces easily spread in less populous locations, Portland remained largely a conservative and business-oriented city. The business representatives in Portland were well established and content with the system as it was, as evidenced by the tone of the City Club discussions, which focused on how to prevent or mitigate change.

This dichotomy violently came to a head during World War I with the first Red Scare. Under anti-sedition acts, the government imprisoned dissenters, even those as prominent as Debs. In Portland, as in many cities, a special branch of the police force was created to monitor and limit dissenters. By the 1920 s, socialism was a shadow of its 
former self. In the 1930s, worldwide labor movements and anxiety over the spread of fascism rekindled ideas of labor equality and moving the means of production amongst old supporters, and likewise rekindled the old fears in those who supported capitalism. These renewed stirrings mixed with the helplessness from the Great Depression led to new hopes and fears of global change. When the Japanese began their propaganda campaign against Chinese communists as well as the Chinese nationalists' inability to stop them, they joined a complex discussion already in progress in Portland.

To understand the entire picture, this chapter will be broken down into three sections. First, there will be a brief introduction to the history of labor in the Pacific Northwest and Portland specifically. The purpose of this section is to establish the latent support for labor-related causes by the 1930s. The second section will focus on both Japanese claims and Chinese counter-claims of communism which were heard in Portland. This section will fully articulate the "Far East Question" as presented to the Portland audience. After the question and contemporary responses to it are fully introduced, the final section will focus on the discourse in the 1930s on communism, Sovietism, and world ideologies in general. The goal of this section, and indeed the whole chapter, is to articulate the reaction in Portland to claims of Chinese communism.

The discussion of Chinese communism is simply more proof that Portland was unique in responding to Japanese propaganda. Because Portland was the only large city in the area, it meant that, in Oregon, both sides of the ideological debate were forced to use the same stage. Subsequently, any large announcements or events were held in 
Portland - as were most guest speakers. The result was that Portland became a complex mix of ideologies and interests, which meant that when outside forces probed Portland for a response the response was correspondingly complex. By tracing the threads of this complexity, this chapter will show the reasons why Japanese propaganda or Chinese counter-propaganda succeeded or failed and explore the meanings of both.

\section{Section I - A Brief History of Labor in Portland}

After the turn of the century, American concepts of identity were still in flux. In the Pacific Northwest, the situation was even more tenuous. Washington was only granted statehood in 1889 , and the realities of travel meant that the entire region could not help but be disconnected from the centers of American culture in the east. Due to this divide, the Pacific Northwest developed strong identities separate from the baseline American identity usually based around industry, ideology, or region. Based on this disconnect, historian Jeffrey A. Johnson has claimed that by the early twentieth century, “the Pacific Northwest was home to some of the nation's most active and hopeful socialists." ${ }^{169}$

Socialism in the Pacific Northwest acted as the gateway to all heterodox political systems, including communism. Socialism was considered an extension of reform politics; a different flavor of the American system of government, rather than a separate ideology. However, it proved to be fertile soil for Marxism; as labor historian Carlos

169 Jeffrey A. Johnson, "They Are All Red Out Here": Socialist Politics in the Pacific Northwest, 1895-1925 (Norman: University of Oklahoma Press, 2008), 4. 
Schwantes notes: "many socialist recruits were innocent of any knowledge of Marx, but they were eager to build a better society to replace the system they knew so well."170 Once Marx's works were introduced in the 1890s, they proved to be popular amongst labor activists. Those who agreed with Marx "found socialism an appropriate, radical platform from which to operate." ${ }^{171}$ Therefore, most radicals aligned themselves with the Socialist Party.

Externally, those classed as Socialists or radicals could be grouped together because conservatives believed they all stood for a radical change in the fundamental American system. Internally, however, those labeled socialists were much more complicated. They were divided by their specific beliefs, ethnic identity, or industrial association. This section will trace the evolution of these heterodox beliefs in the Pacific Northwest and, equally as important, the fear toward these groups and what they represented to orthodox culture.

\section{Before World War I}

Socialism in the United States reached its peak in the decades before the First World War. Increased industrialization across the country led to a wave of labor awakenings. Due to the workforce realizing the leverage they had in the production process, organized labor grew in the industrial capitals of the country. The evolving consciousness of the labor class soon took to the political arena, and labor began

\footnotetext{
${ }^{170}$ Carlos A. Schwantes, Radical Heritage (Seattle: University of Washington Press, 1979), 103.

${ }^{171}$ Johnson, "They Are All Red Out Here," 21.
} 
fighting the corporate establishment on a larger scale. During this period, the Pacific Northwest was imagined as a "promised land" for industrial workers in the East. ${ }^{172}$ To the newly awakened politically-minded laborers, the Pacific Northwest was a blank slate that could be molded separate from the repressive status quo of the East, which inspired a new wave of people heading to the western frontier.

In the Pacific Northwest, unionization began as a response to Chinese labor. Before the immigration act of 1882 , Chinese immigration created a perceived economic threat. The most unnerving trait of the Chinese immigrants was their tendency to work in the traditional Chinese hybrid family/corporation. To Americans, these cliques were threatening because they contracted their wages in an organized manner that could push out any individual laborer. Also, the Chinese reluctance to adapt to American culture further exacerbated their otherness. Though radicalism, violence, and the immigration act resolved these issues, Schwantes believes that the Chinese family-style labor management left an impression of unionism on the American laborers of the following decades. ${ }^{173}$

Due to the history of labor in Washington, the state leaned toward socialist policies even before the American Socialist Party existed. The Populist Party in Washington, essentially a precursor to the Socialist Party, elected the populist John R. Rogers to governor in 1896. When one of the first union organizers in America, Eugene V. Debs, turned to socialism in 1897, he saw the Pacific Northwest as the future of the

\footnotetext{
172 Schwantes, Radical Heritage, 7.

${ }^{173}$ Schwantes, Radical History, 22-25.
} 
party. When Debs toured Washington in 1895 to rally support for his union, he found an enthusiastic audience in places like Spokane. ${ }^{174}$ Subsequently, when Debs rose to prominence as the leader of the ASP, he remembered the region fondly. Support for the Debs presidential candidacy was not limited to Washington, however. When he ran his "Red Express" through the West in 1908, his stop in Portland drew a crowd of ten thousand, which cheered so hard they "shook the rafters" ${ }^{175}$ of the exposition building. While Portland's relative age and more established commercial presence meant less support for labor, there was still clearly a substantial contingent of socialists.

Socialism was the platform of reform from the 1890s onward, and the Pacific Northwest played a large part in American socialism. Washington was the center of the labor movement in the region, and it rightly gets credited with supporting and perpetuating unionism and socialism. Washington played two important roles in the success of labor politics. First, Washington was home to many experimental colonies that perpetuated the idea of the Pacific Northwest as a socialist utopia. Second, after 1909, Spokane, Washington became home to the national newsletter of the Industrial Workers of the World, ${ }^{176}$ one of the most influential unions in the United States. With so much official and unofficial socialist activity, Washington was the unofficial home of socialism.

\footnotetext{
174 ibid, 86.

175 “Old Parties Are Grilled by Debs, Large Audience Hears Socialist Nominee," The Oregonian, September $15,1908,1$.

${ }^{176}$ Where it is still being published today.
} 
Though Portland mostly stood as a bastion of conservatism, the rest of Oregon was not immune to radical ideologies. Debs dreamed of a socialist future for the West, to be accomplished "by founding small socialist communities of miners, loggers, and farmers." ${ }^{177}$ One of the more successful socialist communities was the Finnish settlement of Astoria, Oregon. Astoria was the biggest Finnish socialist community west of the Mississippi, numbering 2,120 people, around $13 \%$ of the total population of Clatsop County in $1910 .{ }^{178}$ Importantly, Finnish radicalism in America was "immigrant radicalism ${ }^{\prime 179}$ that was a method of preserving their culture and society in a strange world. American socialists, on the other hand, were united through ideology. For the Finns, community came before ideology. This commitment to community put the Finns in an odd position, as they fully supported American socialism and communism that matched their beliefs, but not the labor-based socialism native to the Pacific Northwest. Though the Finns "were sympathetic to the union movement,"180 it was not their specific brand of radicalism. Though different, the Finns still joined in with the Socialist Party, continuing the party's trend of gaining the support of diverse groups of radicals, even if they did not fully agree with the ASP.

In the years leading up to World War I, the Pacific Northwest became increasingly "Red." Labor movements led to increased populism, socialism, and

\footnotetext{
177 Johnson, "They Are All Red Out Here," 27.

178 “Historical Census Browser," University of Virginia Library, 2004, accessed November 13, 2015, http://mapserver.lib.virginia.edu/php/.

${ }^{179}$ Paul George Hummasti, Finnish Radicals in Astoria, Oregon, 1904-1940: A Study in Immigrant Socialism (PhD Diss., University of Oregon, 1975), 2.

${ }^{180}$ ibid, 124.
} 
eventually communism. All of these ideologies blended together in the Socialist party, which hit its zenith in 1912, "the height of Northwest Socialism." ${ }^{181}$ When Eugene Debs received an average of ten percent of the vote from the Pacific Northwest states in the presidential election that year, it showed that the Reds had made themselves a threat to the capitalist leaders of the country, and that their future was being realized in the Pacific Northwest. Though Debs did not win in 1912, support still remained; "from 1912 to 1916, activism and optimism increased in the Pacific Northwest as well as nationally." ${ }^{182}$

\section{World War I}

The death knell for the American socialist movement began with the Great War. Typical of wartime mentality, radicalism brought out suspicions about loyalty and patriotism at best, and accusations of sedition at worst. Therefore, the mainstream conservatives who had been the target of socialist critique used this opportunity to regain ground and pass laws that would prove fatal to the radical movement in the years following the war. By the early 1920s, the unified Red wave was all but a dream. Although the radical threat had been subdued, the antiradical sentiments espoused during this period would be the lasting legacy.

By the time America entered the war in 1917, the Socialist Party was in firm opposition of American intervention. Unlike most objectors who based their arguments

\footnotetext{
181 Johnson, "They Are All Red Out Here," 89.

182 Johnson, "They Are All Red Out Here," 127.
} 
against the war on the belief that it was solely a European conflict, the socialists lobbied against joining because it was a war of capitalism. When a wave of hyper-nationalism swept the nation, it led to anti-radicalism and the first Red Scare due to the timing of recent socialist success and their outspoken opinion on the war. The most prominent socialist, Debs, was made an example of in 1918, when he was arrested on sedition charges for publicly challenging the draft. In Oregon, the nationalist, reactionary impulse led to the passing of a criminal syndicalism act, which made distributing radical literature illegal. On February $8^{\text {th }}, 1919$, the secretary to the Socialist Party of Oregon, Harlin Talbert, was arrested under the act. ${ }^{183}$

While external pressures were mounting, the Socialist Party was also breaking apart from the inside. The socialist's utopia failed to capitalize on the momentum gained in 1912. While the numbers of supporters remained constant in the following years, the party was not united enough to gain more ground. Instead, the Socialist Party of Washington suffered heavily from factionalism, which contributed to their failure to make any real gains in the political sphere. Internal strife in the Socialist Party of Oregon “dominated [...] party politics at the expense of propaganda outreach and electioneering." ${ }^{184}$ By 1923, the once powerful party had dissolved entirely. In Oregon and elsewhere, the smaller parties had even fewer barriers to dissolution.

The increased scrutiny on radicals led to two results: the increased factionalism of the Socialist Party and the blurring of the line between radicalism and disloyalty,

183 "Five Alleged Reds Bagged in Portland," The Oregonian, February 9, 1919, 1.

184 Johnson, "They Are All Red Out Here," 135. 
which placed a taboo on being a Red. The factionalism which destroyed the American Socialist Party also caused the creation of smaller niche groups, like communists and unionists. The people sympathetic to labor still existed in the Pacific Northwest, but the fact that being socialist was taboo meant that they had to either cloak themselves in unionism, or commit fully to revolution with communism. The acceptable level of dissent had changed drastically with the war, setting up an interwar period that was complicated by the ghosts of the past. This period of growing polarization created a genuinely unique atmosphere in the Pacific Northwest by the time Japan attacked China in 1931.

\section{The Inter-war years}

The peak of the anti-radicalism movement in the Pacific Northwest took place in Centralia, Washington, on Armistice Day, 1919. A conflict between the I.W.W. and the American Legion led to six deaths and a riot. While the circumstances around the conflict are less than clear, and tensions had been building for several months, it was a polarizing conflict in the public eye. The next day, the Morning Oregonian had six separate stories about radicalism on the front page, four of which were related to the Centralia incident. The overarching theme of these articles is that the American Legion, representative of traditional America, was at war with the radical Reds. Sentiment against the Reds was everywhere, even getting the newspaper of the Finnish Socialists, 
Toveri, boycotted and evicted from the building in which it was published in Astoria by the influence of the American Legion. ${ }^{185}$

The legacy of the Red Scare was the emergence of communism in the Pacific Northwest. Some of those who had previously supported socialism found that the next labor movement was coming out of the Bolshevik revolution in Russia. One notable example is Roseburg native Floyd C. Ramp, who supported Debs' presidential bid with fervor, and then applied that same fervor to communism, so much so that he was arrested under the Espionage Act in 1917. Ramp was far from alone; the Finnish Socialists in Astoria believed the Bolsheviks fulfilled the true goal of socialism, and that whether or not one supported the Bolsheviks "separated real socialists from various types of bourgeois reformers." ${ }^{186}$ As Ramp would label it, communism was simply "a better and more complete organization of society." ${ }^{187}$

Other socialists shied away from the Bolsheviks and communism. For example, many in the IWW who were vehement supporters of the Socialist Party before the war backed away from communism. One such leader was Joseph B. McAllister, the President of the Portland Industrial Union Council right before America entered World War II. McAllister was a member of the Proletarian Party of America - a remnant of the Socialist Party which took many cues from the Bolsheviks but consciously separated from the Communist Party - in the 1930s, and his dedication to distancing himself from

\footnotetext{
${ }^{185}$ Hummasti, Finnish Radicals in Astoria, 189.

${ }^{186}$ Hummasti, Finnish Radicals in Astoria, 189.

${ }^{187}$ Transcript of speech given in Roseburg during 1934 (no other information available), Box 7 of Floyd C. and Benjamin F. Ramp Papers, 1874-1973. University of Oregon Libraries, Archives Department.
} 
communism is evident. While in his letters, McAllister used "communist" as a synonym for "traitor" inside the unions, the taboo was complicated. When he was accused of being a communist sympathizer, McAllister countered:

Now, I do not take any offence at being called a member of any working class political party; but I would certainly blow my top if anyone ever accused me of being a member of any of the political parties of the bosses - of plundering capitalism. $^{188}$

The unionists walked a fine line between supporting labor and supporting America, which McAllister's letters exemplify by how politician-like he answers his accusers. Other documents from before he was president show McAllister satirizing those who question communism, ${ }^{189}$ suggesting that the stigma against communism was coming from external pressures to show loyalty to the United States.

For those who were not socialists, the Red Scare had a more subtle effect. While the Socialist Party was all but a memory, the image of labor as the breeding-ground for sedition remained in full force. "Red" was now a dirty word that inspired images of foreign lands and people coming to destroy the culture of America, rather than the laborer striving for a better future. Memories of the Armistice Day Massacre and the strikes throughout the 1910 s and 1920 s were still fresh. It certainly did not help that there was a constant reminder of the threat communism posed to the establishment by

\footnotetext{
188 4/22/41 Meeting Minutes, Pgs 4-5. Joseph B. McAllister Papers, 1936-1942, University of Oregon Libraries, Archives Department.

${ }^{189}$ There is a whole thing about a society of apes. It is very interesting.
} 
the news reports from Russia (and eventually Mongolia). While the communist threat to the United States as a whole was vaguely unsettling, the threat to the Pacific Northwest was much more palpable.

In order to counter that Red threat, the Portland Police Department started a "Red Squad" sometime in the early 1920 s. ${ }^{190}$ The purpose of this squad was to monitor and police any perceived communist activity in Portland and the surrounding area. However, by the 1930s, they became less of an official branch of the police, and more a set of private investigators for companies hoping to weed out communists. ${ }^{191}$ The members printed pamphlets to dissuade people from supporting communism, ${ }^{192}$ and, according to an ACLU investigation, they abused their powers as police to unfairly target communist sympathizers. ${ }^{193}$ One of the Red Squad's duties was monitoring radicalists, and they took a very liberal stance on who was a threat. For example, J. J. Handsaker ${ }^{194}$ of the National Council for the Prevention of War was on their list of "active communist sympathizers and supporters"195 ${ }^{19}$ solely because of his stance on world peace. The Red Squad was essentially a legal arm of the popular communist paranoia. Though they were shut down in 1937 after the Supreme Court case De Jong v. Oregon, ${ }^{196}$ fear of

\footnotetext{
${ }^{190}$ Since it was semi-official, there was no official beginning. However, it coincided with worries of the I.W.W.

${ }^{191}$ National Lawyers Guild, Oregon Chapter. Civil Liberties Committee, Report of the Civil Liberties Committee (Portland: ACLU, 1938), 37.

192 And published large stories in The Oregonian. See: "Let's Stay American" The Sunday Oregonian, March 15, 1936, magazine page 1.

193 ibid, 12.

${ }^{194}$ See Chapter 2.

${ }^{195}$ National Lawyers Guild, Report, 14.

${ }^{196}$ De Jonge argued that he was legally allowed to speak at a peaceful meeting of the Communist Party, and the Supreme Court ruled that due process applied to the freedom of assembly.
} 
communism allowed the Portland Police Department to go on a witch hunt when there was no immediate threat.

By the time that Japan and China started their propaganda war in the 1930s, sentiment toward communism in Portland was, in a word, complicated. The great political support for socialism - which shares many basic tenets with communism - that remained in the Pacific Northwest was divided and anxious from the increased scrutiny of the Red Scare and the collapse of the Socialist Party. On the other side, those who had learned to fear the socialist radicals transferred that fear to the communists, and this apprehension was only magnified by the Bolshevik revolution. The rhetoric in the newspapers had turned against the Reds, and the precedent of anti-sedition laws from the Great War left official agencies like the Portland Police Department pushing the boundaries of legality in an attempt to protect the public from the scourge of communism. In the Pacific Northwest, communism became the future to some and the bogeyman to others. These people would see Japanese and Chinese propaganda in an entirely different light.

\section{Section II - Japanese claims and Chinese counter-claims}

When Japan invaded China in 1931 and 'liberated' Manchukuo, one of its main reasons for doing so was to create a protective buffer between Japan and Russia. Japan knew that in the past Russia wanted at least economic control over Northeast China. Even though there was a slight reprieve in pressure from Russia during the revolution, Japan still feared that the Soviets would push southward again. To that end, Japanese 
propaganda attempted to justify their actions by playing up fears of communism and Soviet influence in China and the consequence for the world at large. Like most Japanese propaganda, the underlying threat was the cessation of the Open Door policy. What separated this thread of propaganda was that it posed not just an economic threat, but a political and ideological threat as well. If China were to follow Russia, would the Soviet bloc be as open to Western trade and influence as Japan? What if Soviet Marxism spread elsewhere? Communism conveniently gave Japan a target which was largely agreed upon as dangerous to the world.

For their part, the Chinese Nationalist party, the Kuomintang (KMT), attempted to counter the fears of communism for similar reasons. The KMT's solution to unequal treaties and external pressures was to strengthen China. Given enough time and space, China could recreate the success economic success of Japan. Unfortunately for the KMT, Japan and the communists in China were not giving China the time it needed. The problems facing the KMT were two-fold: first, the internal division with the communists was weakening not just China's ability to fend off Japan, but also China's image in the international society by undercutting the KMT's authority. Second, Japanese encroachment on Chinese land threatened not just the sovereignty of China, but the possibility of setting a dangerous precedent.

Internally, the KMT had been fighting with the communist remnants since 1927. The civil war was draining the resources needed to properly defend against Japan, which led to the KMT conceding much to Japan in the years after 1931 to avoid an open war. 
Externally, China leaned on the international system, and the League of Nations which had come to represent it, in an attempt to stop, or at least slow, the Japanese. Japanese propaganda was so damaging to the KMT because any suspicions that the KMT was not entirely in control of China, or in danger of losing power, would significantly weaken their position in the eyes of foreigners. Any claims they made against Japan would be undermined if the rest of the world believed that it was all a communist plot to clear the way for communist ascension in China. Therefore, the only actions the KMT could take while they were still focusing on the communists were to vehemently deny communist influence, assure the rest of the world of their control in China, and direct attention back on Japanese imperialism. The KMT could only hope that other countries believed them.

\section{Proactive Propaganda}

"It is incontestable that the Comintern ${ }^{197}$ is a common enemy of all civilized communities, and its destructive programs and work should be known to all those wishing to preserve the fruits of human progress and heritage." ${ }^{198}$ When it came to communism, there was no middle-ground in the Japanese narrative; communism was evil and Japan was a savior. The only aspect of Japanese propaganda which fluctuated was the depiction of China. Japanese accusations of Chinese communism revolved around three central themes: the failure of Chiang Kai-shek and the KMT to control

\footnotetext{
${ }^{197}$ Short for the Communist International, it was an organization which advocated global communism through any means necessary.

${ }^{198}$ F. Mödlhammer, Moscow's Hand in The Far East (Tokyo: Nippon Dempo Tsushinsha, 1938), Editorial Forward from Hoshio Mitsunaga, President.
} 
China without aid, the threat of the Soviets taking China for themselves, and the threat of communism spreading across the globe. As is inherent to propaganda of this nature, the underlying assertion that the Japanese made was that the KMT, then the national face of China and Japan's direct competition, was incapable of managing China and more importantly for Western countries - incapable of preserving the Open Door policy.

The primary accusation that the Japanese made was that the KMT was vulnerable to communist influence. To this end, Japanese propaganda portrayed Chiang Kai-shek ${ }^{199}$ as the face of the nationalists. However, the portrayal of exactly how much Chiang was swayed by communists varied wildly with the goal of the propaganda. For example, in a simple pictorial primer on the war aimed at the casual reader, the relationship is explained through a series of cartoons in which a traditionally dressed Chiang Kai-shek first shakes hands with a much taller and imposing Stalin, then pulls a sword on him, and finally ends up cradled in Stalin's lap while holding a hammer and sickle. The descriptions paint Chiang as a "dictator" who only came to power with Soviet help and cannot throw off their yoke. ${ }^{200}$ In this piece of propaganda, the most persuasive method of describing the KMT's relationship with the communists between the 1927 expulsion and the 1937 reconciliation was to portray Chiang as entirely under Moscow's control.

\footnotetext{
${ }^{199}$ Who was certainly the most recognizable person in China to Western readers.

200 Japan Pacific Association, What's it All About? Japan-China Pictorial Primer No. 1 (Tokyo: Japan Pacific Association, 1937), 12.
} 
Most Japanese propaganda was not as insulting towards its audience's

knowledge of international affairs, however. Examination of most Japanese propaganda shows that the preferred method of justifying their actions on the continent was to act as the savior to a noble Chinese people under threat of Soviet domination. The benefit of this line of propaganda was that it could also justify working with the Germans and Italians as the guards against communism on either side of Russia. In a piece of German propaganda translated into English and published by a Japanese company, the portrayal of Chiang could not be more different: "[Chiang is] China's greatest living statesman, its leader admiringly recognized by the entire nation."201 This version of Chiang was a noble statesman who was fighting the good fight against the Soviets, but in need of the might of Japan to win the war.

Though obviously much more flattering to the Chinese, lionizing Chiang was just as disingenuous as claiming he was a communist puppet. Maintaining this narrative would have been difficult when the Japanese military was progressively encroaching in China. Therefore, most Japanese propaganda settled on portraying Chiang as misguided and antagonistic, but capable were he willing to cooperate with Japan. It is a fact that Chiang Kai-shek came into power by successfully playing the complicated game of Chinese politics. By playing his opponents against each other, including Japan against the Western world, Chiang consolidated his rule and place as the head of the KMT. However, Japanese propaganda argued that Chiang faced a bigger threat in communism

${ }^{201}$ F. Mödlhammer, Moscow's Hand in the Far East, 155. 
than he had in factionalism, and this threat was one which threatened the whole world: "the ringleaders of [the Chinese communists] are exploiting Communism for expediency - for the help they can thus obtain from abroad - just as Chiang Kaishek [sic]" ${ }^{202}$ had done. It was expedient for Japanese propaganda to portray Chiang as overwhelmed by circumstances.

Portraying Chiang as the true ruler of China was an intelligent choice for Japanese propaganda. It allowed the Japanese to classify their conflict with China as a misunderstanding that was still acceptable in the international society. Instead of a war of conquest, this conflict was simply another in a series of small scuffles between neighbors. Meanwhile, Japan's - and China's - real struggle was against the global plague of communism, and this was the cause for which they were campaigning. When the Japanese Consul in Portland, Ken Tsurumi, spoke to the Portland City Club in 1936, he endeavored to win support by changing the perceived Japanese enemy from China to the Soviets. The consul asked the Club to imagine a hypothetical scenario in which Canada was both communist and in possession of the largest standing army in the world, while Mexico was politically unstable and being actively courted by Canada. "Face to face with such neighbors, what policies do you think the United States would follow in the conduct of her foreign relations?"203 By framing the conflict in this manner, the consul assuaged fears about Japan while simultaneously building the relationship with America.

\footnotetext{
202 Kawakami, Manchoukuo: Child of Conflict, 298.

203 Peace and Order in Asia Declared Vital," Portland City Club Bulletin, 17, no. 15 (1936), 2.
} 
It also allowed Japanese propaganda to present Chiang Kai-Shek as admirably petulant. Propaganda often invoked stereotypes of China as a scheming "master in the art of 'controlling one barbarian by another'"1204 to explain Chiang's method of turning Japan and America against each other. Chiang was simply doing what any intelligent person in his situation would do, which was to use every avenue available to him to increase his power and China's position. He used the Soviets to train his troops and conquer, and then dropped them when it was opportune. He was a master at getting what he wanted from those who hoped to exploit China. Japanese propaganda hoped that by pointing out Chiang's duplicity they could cut off his next attempt by playing up the relationship between the United States and Japan as sympathizers to China's plight of unequal treaties. Ultimately, by either respecting Chiang's abilities or decrying his failures, Japanese propaganda was able to shift attention from the conflict in China to the threat of communism.

For American viewers, the most potent aspect of Japanese propaganda was the threat to foreign trade in China. One of the main points in all Japanese propaganda about China was that "Japan needs China's Open-Door [sic] infinitely more than does the United States." ${ }^{205}$ In this sense, the Japanese angle was to commiserate with the Americans at the prospect of losing the Open Door paradigm, which in this instance was due to the threat of communism. In a 1937 speech, a Japanese supporter claimed that the Bolsheviks were already disturbing the world market and that "hand in hand with

\footnotetext{
${ }^{204}$ Kiyo Sue Inui, LL.D. “The United States and Japan in Asia” (Address, Commonwealth Club of California, San Francisco, CA, April 26, 1940).

${ }^{205}$ Kiyo Sue Inui, LL.D. "The United States and Japan in Asia."
} 
the political infection, they have begun an open economic war against the world." ${ }^{206}$ In this state of increasing pressure, Japan portrayed itself as the best option for maintaining the foreign-friendly Open Door policy.

A more specific threat to Americans in China was the anti-foreign sentiment sweeping through the country. Larger economic themes are threatening, but when the costs of shutting down the Open Door policy were made apparent, the threat became more acute. When real lives were threatened in Shanghai following the Japanese advance there in 1932, Japanese propaganda threatened that the anti-foreign sentiment in China was to blame, stating "it has been the Nanking government's settled policy to encourage anti-foreign and particularly anti-Japanese agitations" and "these agitations [...] have been latterly intensified by Communist propaganda inspired by Moscow." 207 These sentiments are reflected in an article from an American magazine that questions Chinese honesty: "underneath the sham humility of the Chinese is only contempt for Western civilization. ${ }^{208}$ Not only was China at risk of becoming communist, the inherent anti-foreign bias meant that a revolution similar to Russia's would all but guarantee the total expulsion of foreign interests.

Of course, the fundamental threat of a communist China was ideological. Communism was the antithesis of the capitalist American doctrine, and any growth in

\footnotetext{
${ }^{206}$ F. Mödlhammer, Moscow's Hand in the Far East, 97.

207 The Japanese Foreign Office, Aggression at Shanghai (Seattle: Seattle Japanese Chamber of Commerce, 1937).

${ }^{208}$ Hamilton Bulter, “American Delusions About China," The American Mercury, January 1933, p. 105. Accessed May 1, 2015. http://www.unz.org/Pub/AmMercury-1933jan-00103. 
support for communism was unwelcome. While the ideological threat may have been the most obvious consequence discussed, what made the idea of China becoming communist so threatening was the massive size of China and her influential position in East Asia. Japanese propaganda could let the figures talk for themselves: "imagine the Manchurian Empire, with its population of about $35,000,000$ as an anti-Japanese ally of [...] Outer Mongolia and of Soviet Russia." ${ }^{209}$ With numbers so massive, surely the next step would be the entirety of East Asia falling to communism.

The grim scenario of a communist-controlled East Asia that Japan put forward was unintentionally aided by pro-communist and pro-labor propaganda in America. Books like Red Flood Over China by Agnes Smedley or China's Millions by Washingtonian Anna Louise Strong re-assured communist supporters in America that the Chinese communists were still fighting and slowly winning the good fight. These would simultaneously support the Japanese claims of communist intent in China and the portrayal of Chiang Kai-shek as a misaligned ally in the fight against communism.

Japanese propaganda made it clear that the biggest threat in China to foreign interests was Soviet influence, and Japan's position on the front line meant their actions should be considered as fighting for all those involved with China. By using Chiang Kaishek as a representative for all of China, Japanese propaganda was able to adjust their message to gain the desired results by changing the character of Chiang. However, no matter how they depicted Chiang, the overall message was that the real enemy was

\footnotetext{
${ }^{209}$ F. Mödlhammer, Moscow's Hand in the Far East, 95.
} 
Soviet communism, which was a threat to both the world economy and the world order. Reviewing all of this propaganda shows that the Japanese were not only extremely dedicated to convincing the American audience, but adept at crafting effective propaganda.

\section{Reactive Propaganda}

China was on the defensive in both the ground war and the propaganda war against Japan. Much like on the battlefield, the Chinese were the ones with ground to lose, and entreated upon foreign powers for assistance. Therefore, Chinese propaganda took one of two forms: explicitly countering Japanese claims, or attacking the Japanese while elevating China's role. To counter Japanese claims, the Chinese propagandists had to make a unified front. Most importantly, while Japan's propaganda could change its message to suit its needs, Chinese propaganda had to remain consistent. Perhaps because of the nature of defense, the method of Chinese propagandists was also different. Instead of the glossy books with photographs found in support of Japan, most Chinese propaganda was either in the form of lectures or small, pamphlet style publications. The quality of publication showed that Chinese supporters were less organized and much less funded than their Japanese counterparts.

The necessity for China to appear unified was paramount. China already had the upper hand, having "the sympathy of almost the entire world" ${ }^{210}$ on its side. In order to

\footnotetext{
${ }^{210} \mathrm{Hu}$ Shih, "The Issues Behind the Far Eastern Conflict" (Address, Foreign Policy Association, New York, November 13, 1937).
} 
maintain appearances, Chinese propaganda also used Chiang Kai-shek as a figurehead for China. However, unlike the Japanese, the Chinese depiction of Chiang was singular. Chiang was not a communist conspirator or a scheming mastermind aiming to pit one nation against each other. Instead, Chiang was portrayed as the great Generalissimo. He was "a man strong in character, upright in spirit and imbued with deep religious convictions." 211 It was "his moral strength and his intellectual leadership [which] brought about a unified China." ${ }^{212}$ He was the perfect leader for the emerging nation.

A unified country needed two things in the 1930s: a strong leader, which China had in Chiang, and a solid founding principle. China as a modern nation instead of an antiquated empire was a new notion; it was only in 1911 that the Qing dynasty was finally overthrown. Chinese propagandists reminded the American reader that "nationalism is a new word in the Chinese dictionary, but national consciousness has never been absent in Chinese history." ${ }^{213}$ Instead, it was only a change of classification for the Chinese people. Instead of being subjects, the people were now citizens of the Chinese nation. This change was brought on by China's own founding father, Dr. Sun Yat-sen. It was Sun's beliefs on government which brought the concept of popular sovereignty to China. ${ }^{214}$ For this, Sun was canonized to the point where Chinese supporters claimed that "though his mortal body is dead, his memory lives on in the

\footnotetext{
${ }^{211}$ Harry McNeill and West Meets East Committee The Truth about Communism in China (New York: West Meets East Committee, 1939) 6. This is a transcript of a speech given by Bishop Paul Yu-pin, Vicar Apostolic of Nanking.

212 ibid, 7.

${ }^{213}$ Hu Shih, "The Issues Behind the Far Eastern Conflict."

${ }^{214}$ Which the Nationalists and Communists were then fighting over how best to realize.
} 
hearts of 450 million Chinese." ${ }^{215}$ With Chiang and Sun Yat-sen, the Chinese had requisite ingredients for a modern unified country.

The necessities being fulfilled, Chinese propaganda was able to combat Japan's core claim, declaring instead that the war was neither a misunderstanding nor a small spat; it was "the Chinese nation fighting for its very existence." ${ }^{216}$ While Japanese propaganda downplayed the war with China in favor of the ideological battle with communism, Chinese propaganda instead emphasized the war with Japan as a clash between freedom and fascism. The KMT had made it a point to use the rules of the League of Nations as guidelines for their conflict with Japan, and by doing so showed their allegiance to the Western system of rule. Therefore, Chinese propagandists could make grandiose statements like "this war is a struggle between democracy and military autocracy." ${ }^{217}$ Chinese propaganda made sure to point out that this conflict was not merely a local struggle, but that Japan had set an example for the other militaristic nations, like Germany and Italy, by defying the League of Nations.

Because of its reactive nature, Chinese propaganda could and did attack everything about the Japanese platform, but it did not answer Japanese claims of communism in China. To that accusation, the Chinese response was generally dismissive. Instead of rising to the bait of Japanese claims - especially the audacious ones about Chiang being a Soviet puppet - Chinese propaganda relied on the global understanding

\footnotetext{
${ }^{215}$ Harry McNeill and West Meets East Committee The Truth about Communism in China, 6.

${ }^{216}$ Shih Hu, "The Issues Behind the Far Eastern Conflict."

217 "Chinese Consul Condemns Japanese Aggression," The Portland City Club Bulletin 18, no. 30 (1937), 8990.
} 
of China's ongoing struggle with communism. China's struggle with communism was widely known, and became a double-edged sword. On one hand, it supported Japanese claims that China was at risk of being taken over by communists. On the other hand, by claiming that their struggles were overblown, or after the 1937 alliance with the Communists in the Second United Front, in the past, it validated the existence of the KMT. Thus, Chinese propaganda could recognize the threat that communism is to China, but at the same time build up the Nationalist government.

For example, in a 1935 speech by the Chinese ambassador to the USSR at the League of Nations, he said that communism was "one of the greatest obstacles to the stabilization and unification of the country." ${ }^{218}$ However, this admission was quickly followed with an assurance that the KMT was "duty-bound to curb [communism's] growth with all the means and energy available" and that "the backbone of the Communist armies has been broken, and it is only a matter of a short period of time before China will be rid of the entire Communist movement." ${ }^{219}$ This same attitude was present in 1937, when the Chinese consul in Portland, Shang Chi Su, assured the City Club that "as for communism, China has succeeded in erradicating [sic] that form of organization." ${ }^{220}$ Rather than denying the claims, the Chinese officials met them head on and attempted to pacify Western fears by claiming victory over the communists.

\footnotetext{
${ }^{218}$ Transcript appearing in Department of Western Languages, In These Times (Peiping: Yenching University, 1936), 43.

219 ibid.

220 “Chinese Consul Condemns Japanese Aggression," The Portland City Club Bulletin 18, no. 30 (1937), 8990.
} 
The next step for China in responding to accusations of communism was to question Japan's role. Common sense showed that while Japan was talking up the threats of communism, they were still at peace with Soviet Russia. Moreover, the Japanese actions in China were portrayed as actively promoting Chinese communism by distracting the KMT or other anti-communist forces. A 1932 book by Ching-Chun Wang claims that Japan's timing when invading Manchuria was just in time to save the reds by "pulling Nanking's legs from behind." ${ }^{221}$ Ching-Chun Wang also points out that the Manchurian warlord, and one-time ally of Japan, Zhang Zuolin had always been against Sovietism, as was his son, Zhang Xueliang. However, Zhang Zuolin was "dynamited to pieces $^{\prime 222}$ by the Japanese for failing to hold off the KMT. Consequently, Zhang Xueliang conspired with the communists to force Chiang Kai-shek to unite against Japan.

By using reactive propaganda, the Chinese presented a case that answered all of the Japanese claims while simultaneously directing criticism back toward Japan. Chinese propaganda presented a united front by presenting the charismatic Chiang Kai-shek as a true leader with Western ideals who played by the rules of international diplomacy. By doing so, this propaganda turned Japanese attacks on China into attacks on the very concept of democracy and freedom. The big question left for Chinese propaganda to answer was the claim that communism was growing in China, which they dismissed as being overblown by the Japanese as a casus belli to invade China. When discussing Japanese propaganda, one Chinese bishop called the menace of communism "an ideal

\footnotetext{
${ }^{221}$ ibid, 13.

${ }^{222}$ Ching-Chun Wang, Whither Manchuria? (London: Fish \& Cook, 1932), 12. 
camouflage for the political domination and economic exploitation of the Chinese nation and to befool and befuddle the American people."223

\section{The Successes and Failures of Propaganda}

Both Japanese and Chinese propaganda deftly defended their actions and placed the blame on the other. The Japanese claimed that the KMT was incapable of securing China. The Chinese claimed that Japan was militaristic with imperialist goals, while both blamed the other for communism in China. The American reader was left to separate fact from fiction and make a judgment. In the end, it came down to two questions. First, was Japan really the benevolent force it claimed to be in Asia, especially about keeping China open and preventing the spread of communism? Second, was China really as unified and Western-minded as its propaganda claimed?

\section{Section III - Northwest Opinions}

The history of socialism and labor movements in the Pacific Northwest, the enthusiasm with which the Japanese sold their message, and the Chinese debunking of Japanese propaganda caused a varied response in Portland. From hearing visitors speak on the issue to reading one of the top foreign correspondents in the Far East, Portland was sincerely interested in the goings on in East Asia in regards to communism.

\section{Interactions with and thoughts on the Soviets}

\footnotetext{
${ }^{223}$ Harry McNeill and West Meets East Committee The Truth about Communism in China, 21.
} 
After the Bolshevik revolution in 1917, communism became synonymous with the Soviets. Because of this relationship, studying any direct interactions with the Soviet Union and the reaction to those interactions is enlightening. Though Portland had relatively few interactions with the U.S.S.R, these interactions drew an intense interest. What is most interesting about these interactions is how Soviet Russia was portrayed. Depending on the situation, the emphasis might be placed on either the ideological identity or the ethnic identity of the Russians. From hearing experts on the Soviet Union to being an unexpected partner in a milestone, Portland remained intrigued about the U.S.S.R through the 1930s.

Though many experts who visited Portland spoke on the issues of the Soviets and the future of Asia, the most prominent of those was probably Victor A. Yakhontoff, a former Czarist major general who had fled to the United States, where he gained citizenship. Yakhontoff came to speak in Portland in 1937 at the behest of the Portland branch of the American Friends of the Soviet Union. By this point, Yakhontoff had written two books specifically about Russia and East Asia, and his Portland lecture was on the same topic. In both his books and this lecture, Yakhontoff was oddly quiet about the ideological aspect of the Soviets for a Czarist expatriate. Instead, he (rather cynically) treated the Soviets as merely the next Russian government. It is possible that he refused to believe that there was any inherent superiority in communism, so he described the U.S.S.R. in strictly practical terms. 
However, Soviet Russia and communism were mostly thought to be inseparable and a global threat. During the debate for recognizing the U.S.S.R., the ideological threat was often exaggerated. In one Oregonian opinion piece, the author warns that the "communist threat to the United States is real," 224 and that the only way to combat that threat was to prevent the Soviets from recruiting in the U.S. and spreading their propaganda here. As for the internal communists, the author simply states that "the communist party should be suppressed."225 But, in a 1933 counter argument, the Russians were on a level plain with the rest of the world's governments: "The American public and the American government can continue to think what they please of communism; [...] recognition is merely an aid to business, and an admission of comparative stability. ${ }^{226}$ Simply put, there was no uniform opinion when it came to the Soviets, only a measure of how much of a threat they presented to the United States.

Portland's direct relationship with the U.S.S.R was unremarkable before 1937, when it became truly unique. On June 18th, 1937, the world's first transpolar flight left Moscow headed for San Francisco. Due to unforeseen circumstances, they made ground at Vancouver's Pearson airfield. Though achievements such as this are usually separated from politics, the purpose of this flight was not only to test boundaries; the flight was the pride of the Soviet Union. The route was labeled the "Stalin route,",227 and upon completing the flight, one of the pilots wrote "A new route, joining two worlds across

\footnotetext{
224 “Defense Against Revolution" The Oregonian, January 19, 1931, 8.

225 ibid.

226 "The Overture To Russia” The Oregonian, October 22, 1933, 10.

227 George Baidukov, Over the North Pole (New York: Harcourt, Brace and Co, 1938), 98.
} 
the inaccessible Arctic, has been opened by Soviet flyers." ${ }^{228}$ Clearly, the goal of this milestone was as much about national pride as it was about aeronautics.

How was such an accomplishment treated in the city that was previously unaware it would be a part of it? The first response to such a feat was, of course, admiration. The next morning's Oregonian featured four full pages of pictures and at least six individual stories of the "polar heroes." ${ }^{229}$ Indeed, the airmen were the subjects of a parade the next day, cheered on by thousands. ${ }^{230}$ Outside of the standard stories discussing the flight and the situations of the landings - including an interview with a woman who spoke enough Russian to simply say hello to the pilots - the most striking part of the coverage is what was missing. Only one small article, from the AP, mentions that the Soviet government attributes the flight's success to socialism. In response to that statement, one opinion in The Oregonian asked "what has politics to do with this enduring accomplishment whose fame will outlast many theories and governments?" ${ }^{231}$ It seems that Portland was simply happy to be a part of such a monumental achievement.

These examples show that the understanding of the Soviet Union and Russian communism fluctuated in Portland. For the most part, it appears that the older the U.S.S.R became, the easier it was to accept that the country was just like any other. The Red Scare mentality was still present, as evidenced by the perceived threat of just

\footnotetext{
228 ibid, 99.

229 The Oregonian, June 19, 1937, 1.

230 "Heroes of Flight Soar to Oakland" The Oregonian, June 22, 1937, 1.

231 "The Three Arrive From Moscow" The Oregonian, June 22, 1937, 8.
} 
recognizing and doing business with the U.S.S.R., but the magnitude of the communist threat was lessened when it seemed that America was not directly in danger. Perhaps there was also a little overconfidence remaining from the resounding defeat of socialism in the U.S. Either way, by the 1930s, Portlanders were more than willing to view the Soviets as Russians first and communists second, as evidenced by the discussions treating the U.S.S.R. as any other nation and the arrival of the Soviet pilots. While the threat of communism was still real, it appears that there was simply too much of a disconnection between the Soviets and the radical threat. Instead, the biggest threat the Soviets posed was the precedent they set for global revolution, the threat of which dissipated with time, especially after Lenin's death.

\section{Pro-communist Reactions}

As citizens of the Pacific Northwest, the opinions of those who supported communism were also important, even though their voices were few. One of the preeminent American voices in support of the U.S.S.R. was Anna Louise Strong, a onetime resident of both Seattle and Portland, and then an associate editor of an English language newspaper in Moscow. In an effort to learn about Chinese communism, she traveled to the interior of China to see how students were converting the peasants and farmers to communism, a job that was made easier because of the struggles those peasants had faced. Eventually, Strong met with the Chinese Communist Party and fled with the main Soviet instigator of communism in China, Borodin, to Mongolia. In her book describing the journey, Strong powerfully states that "America is the strongest and 
greatest imperialist in the world!"232 because the financial support - through open trade and development - that the American government has given to Japan and the KMT.

Despite her decidedly un-American message, The Oregonian's review of Strong's book was glowing, stating that as "sympathetic as [Strong] is with the cause, she lets the facts rather than feelings tell the story." ${ }^{233}$ Further, Strong spoke about her experiences in Russia at the Benson Polytechnic School in 1936. In her lecture, she stated plainly that "Russia doesn't want war," and that while Russia was prepared, the only way it would go to war was if Japan or Germany attacked. ${ }^{234}$ That these comments were left to stand without criticism is telling. For one, this is the same person whom The Oregonian disparaged against for her vocal complaints against American involvement in World War I. ${ }^{235}$ At this point, regardless her inflammatory comments, Strong was treated as more of an expert on Russia than a revolutionary.

For the general American public, several communist sympathizers became the face of the communist threat at home. Amongst these sympathizers, two of the most recognizable were Portland's own John Reed and Louise Bryant, his wife. While Reed was the more famous of the two and has a legacy of capturing the romanticism of revolution in Russia, both were considered the foremost authorities on the Russian revolution. While Reed's literary accomplishments are many, he also led a fantastically tumultuous life. He was a frontline reporter in Mexico during the revolution, in the

\footnotetext{
${ }^{232}$ Anna Louise Strong, China's Millions (New York: Knight Publishing Co., 1935), 456.

233 "Communism in China Gets Light Turned on It" The Sunday Oregonian, December 1, 1935, 53.

234 "Russia Declared Opposed to War" Oregonian, March 17, 1936, 3.

235 One example: “A Hotbed of Treason” Oregonian, November 13, 1917, 11.
} 
trenches in WWI, and a witness to the revolution in Petrograd. His fame turned to notoriety in the U.S. when he became a convert of Bolshevism and helped found the left wing of the American Communist Party. Consequently, he was arrested several times and tried in the U.S. for sedition, though he never spent much time in jail. His position with the Bolsheviks was so high that, for a brief moment, he was appointed their ambassador to the U.S., and he was buried a hero in the wall of the Kremlin. ${ }^{236}$

In Portland, Reed and Bryant's celebrity was complicated. Much like Matsusaka, the fact that people important in global affairs was at first a point to brag about; The Oregonian repeated the fact that he was educated in Portland and still considered it his home when he left for Russia in $1915 .{ }^{237}$ However, by 1919, Reed and Bryant were "former" residents of Portland, and their Bolshevik leanings made them unpopular. When Bryant visited Portland in 1919, the Central Labor Council wrote in to The Oregonian to make a declaration that they did not support her nor did they want her to speak publically while she was in Portland. ${ }^{238}$ When Reed was arrested yet again for sedition in 1920, The Oregonian noted that "after completed his education he passed little of his time here and in recent years only made brief visits to Oregon."239

When Reed died later in 1920, the reaction in The Oregonian was surprisingly more kind than it had been while he was alive. Calling him once again a "Portland boy,"

\footnotetext{
${ }^{236}$ Eric Homberger, John Reed (Manchester: Manchester University Press, 1990).

237 "John Reed, of Portland, goes to Russian Front," The Oregonain, April 4, 1915, 2.

238 "The Case of Miss Bryant," The Oregonian, March 28, 1919, 11.

239 "John Reed is Arrested," The Oregonian, March 18, 1920, 2.
} 
the article recounted his adventures with a sense of awe. ${ }^{240}$ Apparently, once Reed could do no more damage to his reputation, he was welcomed back to the Portland fold. The intrigue of his life was simply enough to outweigh his unpopular political beliefs. The reaction to Reed's life in The Oregonian, and indeed Matsusaka's as well, shows that the desire to have a homegrown celebrity sometimes outweighed the sense of national loyalty.

The Finnish Socialists in Astoria were the closest pro-communist group to Portland, and their response to spread of Soviet communism was handled quite differently compared to the general population. For one, the more radical Finns had wholeheartedly accepted Soviet communism as the future of socialism. Convincing the remaining Finns would prove difficult, however, since an integral part of the Finnish Socialists had been their ethnicity and autonomy. The global scale of communism led to disharmony because the Finnish radicals disliked having "to obey without question policies that they had no part in shaping." ${ }^{241}$ This need for individualism led to a schism in the Finnish community. The radicals chose to re-shape the core of their identity by choosing ideology over ethnicity. The schism led to the Finnish paper being taken over by conservatives in 1931, ironically at the same time six people involved with the old paper were arrested for being foreign communists. ${ }^{242}$ The corresponding trial was covered in The Oregonian, where those accused were labeled as ungrateful of the

\footnotetext{
240 "Short Life of John Reed Filled with Startling Incidents and Adventures," The Oregonian, November 7, 1920, Section 5, 1.

${ }^{241}$ Hummasti, Finnish Radicals in Astoria, 381.

242 "Finnish Cases to Open" The Oregonian, June 9, 1931, 11.
} 
country which gave the Finns shelter after they fled from the Russians, saying "they tried to tear down the roof over their own heads." ${ }^{243}$ By associating with the communists of the world and the Communist Party of America, the Finnish radicals lost their influence and eventually disbanded. The pre-eminent socialist group in the Pacific Northwest was essentially brought down not due to anti-radical pressure, but instead by adhering to the global communist ideology coming out of Russia.

Though these two examples seem disparate, they demonstrate that - even in the one-time "Red utopia" of the Pacific Northwest - socialism and communism were dominated by the Soviets. For radicals in America, this new identity meant either conforming to the new Soviet Comintern ideologies or facing ostracism and irrelevance. For some radicals, there was no way to win. The Finnish radicals in Astoria found that there was no way of reconciling the ethnic identity that made them so powerful in the first place and the new demands of the Comintern. These examples also show that, much like Vivian Gornick describes in The Romance of American Communism, communists were real people. Communism is an ideology, the Bolsheviks were a foreign group threatening revolution, but American communists were just people that had their own reasons for believing in communism. Though conservatives in America would join all three together as needed for their narrative, it is important to remember the human aspect of the communists in America.

\footnotetext{
243 "The Toveri Editors Case" The Oregonian, May 8, 1919, 10.
} 
For conservatives and traditionalists in America, the marriage of communism to the Russians allowed the threat of communism to become one of foreignism. When the United States officially recognized the U.S.S.R. in 1933, the unknown became the known, and the fears of communism in the U.S. correspondingly declined. Communism had gone from an ideology that threatened the American way of life to a tangible entity, the U.S.S.R. Once the maps were re-drawn and the borders understood, Americans could reimagine communism as a foreign ideology that posed no more threat than any other. At the same time, the Great Depression caused the American public to become more inwardly focused and sympathetic to laborers, which also lessened fears of communism. What made the Socialist Party so threatening was that it was American in identity, and represented a real rebellion of United States' citizens. In comparison, the perception of communism as foreign-based made all of the difference to the American public.

\section{News from the Front}

As I have shown, communism as an abstract concept and communism as a threat to the traditional American lifestyle was tied to the U.S.S.R. in the 1930s. Therefore, if the United States was not at war with the U.S.S.R., then there was nothing to fear. So, what then did Oregonians think of the Japanese accusations? If communism was not an explicit threat to the U.S. from the U.S.S.R., would it be a threat coming from China? The easiest way to gauge public opinion on the matter is to review the daily newspaper, The Oregonian. The trouble with this method is that then, as now, most local newspapers would not have a dedicated correspondent placed somewhere like China, but would 
instead purchase stories from the Associated Press. Thankfully, The Oregonian did have a correspondent in Shanghai, though not entirely of their own doing.

Mr. Hallett Abend was the Far Eastern correspondent for the New York Times from 1926 to 1940. His reporting in Shanghai and his firsthand witnessing of Japanese atrocities made him an authority on the situation in China. Abend would write two prominent books on China, Tortured China in 1930 and Can China Survive? in 1936. This man was one of the most informed Americans on the events in China and the rising tensions in the Far East. ${ }^{244} \mathrm{Mr}$. Abend was also born in Portland ${ }^{245}$, and apparently remembered his hometown fondly, as he also sent direct and exclusive correspondence to The Oregonian. By sheer luck, a man with such an inside view as Abend was giving his opinion directly back to Portland. By reviewing Abend's articles and opinion pieces in The Oregonian during the 1930s, historians can gain a better understanding of Pacific Northwest opinions on communism in China. More specifically, it is possible to see whether Japanese propaganda was effective at sowing seeds of fear of communism, if Chinese counter-propaganda was enough to direct suspicion back at Japan, or if the first Red Scare had any influence on the mainstream public opinion in Oregon.

Abend, as a correspondent in China, represents a unique view. In his first book on the matter, he warns that "if even a portion of China comes under the rule of what,

\footnotetext{
${ }^{244}$ This is not hyperbole. Mr. Abend "developed his own intelligence service using sources in both the Chinese and Japanese armies prior to the American entry into the war." This is how he got the scoop that Japan was allying with Germany and Italy four days before it was announced. All info from: Roth, Mitchel P. Encyclopedia of War Journalism - 1807-2015 -3rd Ed. (Grey House Publishing, 2015).

${ }^{245}$ However, there are conflicting reports that he was born in Spokane, which is close enough.
} 
in name at least, is called a Soviet Republic, the effect upon most of Asia will be profound and perilous." ${ }^{246}$ From the beginning, it is clear that Abend sees communism as the worst possible outcome for China and the world at large, and sets the communists as villains. His reaction in 1931 to the students pushing communism on the poor and disenfranchised was that the failure lies not with the students, but with the government that failed these people so much that they would jump at communism. ${ }^{247}$ By 1932, his reporting on the communist victories supported the Japanese message, writing that the victory exemplifies "the complete breakdown of all authority claimed by the Nanking government.."248 According to Abend, there just was not much going well for China in the early 1930s.

For the Japanese propagandists making the very same accusations, reports such as these were extremely helpful. Reports detailing the KMT's failures to the Chinese people and their inability to stifle communism surely gave credence to Japan's message, but what is truly striking is the comparison to the tone taken when discussing Japan. On the very same page as one of Abend's articles detailing the Chinese struggles, there is a large picture of a pristine Japanese battleship with a corresponding story about the successes of the Japanese armed forces. ${ }^{249}$ The disparity highlights how The Oregonian portrayed Japan as an imperialist country, but not inherently evil. Japanese victories were noted in the standard newspaper tone of disinterest, whereas Chinese failures

\footnotetext{
${ }^{246}$ Hallett Abend, Tortured China (New York: Ives Washburn, 1930), 25.

247 "Northwest China overrun by Reds" The Sunday Oregonian, April 19, 1931, 2.

248 "Drive on Bandits Fails" Oregonian, June 27, 1932, 16.

${ }^{249}$ Oregonian, September 18, 1933, 12.
} 
were described in excruciating detail, especially when it came to communism. Whether intended or not, Abend's unique reporting from the front in China, compared to the reporting on Japan, made The Oregonian more critical of China than Japan.

In his 1936 book, Abend continues his criticisms of China by rationalizing Japanese actions. He compares the Japanese to the Romans in how they would like to rule China - that is, more like a protectorate than direct rule. He follows this by stating that "Japan does not want the responsibility of ruling China, but she wants law and order in China, and she wants real security for Japanese investments and other vital interests in that country." ${ }^{250}$ Finally, he wonders why the Soviet Union had been given a pass from China and the world at large when it "has filched away territories many times the size of the provinces involved in Japan's incursion into Manchuria and Jehol." ${ }^{251}$ This same attitude was represented in The Oregonian in opinion pieces, which described even the most transparent of Japan's imperialistic moves - such as the crowning of Henry Pu-yi as emperor of Manchukuo ${ }^{252}$ - in a matter-of-fact manner. The overwhelming sentiment for the first years of the conflict was that Japan and Russia both wanted to keep China from the other, but whereas Japanese imperialism was benign, the Soviets' version came with the added threat of a dangerous ideology.

For the first half of the 1930s, the combination of Japanese propaganda and a learned distrust of communism had swayed the opinion of Portland in favor of Japan.

\footnotetext{
${ }^{250}$ Hallett Abend \& Anthony J. Billingham, Can China Survive? (New York: Ives Washburn, Inc., 1936 251 ibid, 242.

252 "Henry, The Incubated Emperor" The Oregonian, January 13, 1934, 10.
} 
Though it is impossible to say whether or not Japanese propaganda was effective, Chinese counter-propaganda was not effective enough to counter it. However, there was a limit on the amount of trust Oregon placed in Japan. When Japan attacked Shanghai in August of 1937, a few (supposedly) errant shells hit the international settlement, killing a few foreigners and injuring many more. This attack appears to be the beginning of the change in opinion against Japanese imperialism. The final blow was the massacre at Nanking in 1937-1938. No longer was it assumed that Japan was simply playing the game of nations. After Nanking, Japanese militarism replaced Soviet communism as the worst possible outcome for China and the world at large.

One of those injured in the attack on Shanghai was Hallet Abend. His injuries, understandably, caused his opinions to change. After his recovery, some of his first reporting was on the Nanking massacre. His report detailed Japanese savagery of the Chinese forces and the Chinese civilians, specifically the women. It is also implied that this was not a singular incident, but just the one for which foreigners have been present to witness. It leads Abend to state that "Japanese soldiers are under suspicion of being on a distinctly lower moral plane than the soldiers of the western powers." ${ }^{253}$ At this point, it was obvious that Japan was not just another imperialist power.

From 1938 on, the opinion of the newspaper is firmly in favor of China. Japanese warnings of a communist future in China were apparently palatable to Oregonians when the Japanese themselves acted as Western nations had done before. It was much easier

253 "Morals of Japanese Army" The Oregonian, March 12, 1938, 10. 
to detail the multitude of KMT failings and the suffering of Chinese civilians when Japan was, for the most part, playing by the rules. As soon as Japan crossed the line, however, the focus shifted to the Japanese. The writings of Hallett Abend in The Oregonian show a clear line of understanding for the Japanese up until 1937-1938. Realized fears of communism played a part in their kind treatment of Japanese aggression at first, which may have been stoked by Japanese propaganda. However, this unspoken support was broken the minute Japan began committing war crimes in full view of the West.

\section{Better Dead than Red?}

The history of socialism and radicalism in the Pacific Northwest had conditioned the traditionally conservative Portland to become a beacon of anti-radicalism by the early 1930s. When the Japanese accused the Chinese of not doing enough to stem the global tide of communism and insisted the only way to quite literally save the world was to invade China, Portland was more receptive to the message than the rest of the country because the threats of communism and radicalism were not only once realized, but realized in the recent past. Because of the established trust in Japan, Portland, as represented by The Oregonian, was much more willing to trust that the Japanese were just in their actions in China, even if these actions were blatantly imperialistic.

Whether or not the Japanese propaganda was responsible for agitating fears of communism in Portland is uncertain. Regardless, the fear of communism was one of the leading concerns in the response to the Far East problem, especially in The Oregonian. In the first years of the conflict, the two most important questions about Japan's 
involvement in China were in regards to the Open Door policy and communism. This thesis has already discussed the reasons why there was a concern over the Open Door policy - it was the United States' greatest interest in Asia. That being the case, one must assume that communism was the United States' biggest fear in Asia as far as Portland was concerned. Japan's militarism and imperialistic goals were simply not as threatening to America as the prospect of a Soviet China joining the U.S.S.R. and creating a Soviet bloc.

However, the fear of communism and the trust in Japan could only go so far. When the Japanese began to get into the indefensible part of a war of conquest, public opinion turned. I believe this to be a failure of Japanese propaganda. If the propaganda had done a good enough job, the American public would have supported the Japanese no matter the cost because they were fighting the most important battle - the battle against communism. It is tempting to think that if Japanese propaganda failed, then it must mean Chinese counter-propaganda succeeded. From all appearances, this is also not true. China was always the victim in this battle, and presented a consistent front throughout. The American public - especially Portland - only chose to listen to the Chinese when it became easier than defending Japanese actions.

Public opinion in Portland was no different from the rest of America in regards to Japanese aggression by the late 1930s. Where Portland differed was the reasons why they chose to first ignore, and then later listen to, Chinese claims. While the rest of the country worried about Japanese imperialism and the East Asian order earlier on in the 
conflict, this was given a pass in Portland. The history of socialism and the established relationship with Japan led Portland to extend their trust in Japan further than the rest of the United States. It was only when the Japanese atrocities began to outweigh the Chinese failures that Portland could no longer defend Japanese aggression, by omission or otherwise. Even Portland, which had both a solid relationship with Japan and a realized fear of communism, could fear the Soviet Star over the Rising Sun for only so long. 


\section{Lasting Relationships}

With the world in the throes of the Great Depression and the rise of heterodox political philosophies, it is tempting to see the 1930 s as the set-up to the cataclysm that was World War II. However, overlooking the minutiae can lead to viewing the past in a series of absolutes - as the stories of winners and losers, good and evil. The case of Portland in the 1930s shows us that the intricacies are central to furthering our understanding. Elaborating on the relationships between Portland and Japan and Portland and China reveals a nuanced and complicated web of associations that go against the general understanding of the pre-war era.

American opinions of Japan and China fluctuated in the years leading up to the 1930s. When America came into global awareness, China was already on the decline, which promoted a belief that China was a stubborn and proud country, and had been surpassed by Western progress. Meanwhile, Japan had begun a dedicated act of "catching up", an endearing movement to the West because Japan accepted its position as a lower-tier country. Around the turn of the century, Japanese dedication to growth began to pose a threat to the West, which shifted the perception of Japan from admirable to dangerous; Japan was a victim of its own success. China, on the other hand, had struggled very openly with adapting to Western-dominated global politics, remaining weak during the process. The Chinese willingness to adapt to Western political norms and the fact that China did not pose a threat to the status quo caused 
Americans to see China in a sympathetic light. By the 1930s, Japan had already transitioned to an imperialist threat, while China became the admirable underdog.

The role of the Great Depression in this change cannot be ignored. Japan's decision to move to the gold standard worsened the effects of the depression there, while China's inability to get off the silver standard sheltered it from the worst of the depression. Japan's dire situation led to increased jingoism and a desire to create economic stability in East Asia via a forced economic sphere. ${ }^{254}$ China, on the other hand, could afford to patiently wait out the storm and play by the international rules. Subsequently, the Great Depression had no real effect on the image of China in the international society. Japanese desperation, however, had a direct effect on their international image. When Japan took control of Manchuria, its image changed from benevolent to aggressive.

In Portland, however, the image of Japan was not firmly set. While the federal government and the general American opinion had classified Japan as a threat, the opinion in Portland had yet to turn against Japan. The business and labor-oriented demographics in Portland had seized upon the opportunity to build an economic relationship with Japan, and was reluctant to abandon it. This reluctance is evidenced by the direct interactions with Japan that occurred in Portland, like the America-Japan Student Conference, and by the attention given to the Far East problem by both the Portland City Club and The Oregonian. These interactions reveal that Portlanders were

${ }^{254}$ Iriye, “Japanese Aggression and China's International Position 1931-1949," 492. 
hopeful for a peaceful reconciliation with Japan, and believed that the solution to the rising tensions was direct interaction between America and Japan.

Lastly, the aspect of the Far East problem that Japan publicized the most was the threat of Soviet communism. This claim resonated with the residents of Portland because of its recent struggles with communism. Though the Red Scare had mostly abated, there was still a red squad in the Portland police department, and Portland observers vocally supported the Japanese goal of stopping communism. The support for Japan in Portland was based upon a developed economic relationship and coinciding ideals. Supporting Japan became more and more difficult, however, as the war with China developed into a war of attrition. By the time of the massacre at Nanking in 1937, even as ardent a supporter as Portland could no longer morally side with the Japanese. It is tempting to believe therefore that China and its supporters won the propaganda war against Japan. The evidence, however, shows that many Portlanders accepted Chinese claims only when they could no longer support Japan.

This study evidences the complexity of the relationship between Japan and America, and how the relationship with Japan has seemingly always taken precedence. The relationship between America and China seems to have been a relationship built around people (i.e. laborers, trading companies). China's diplomatic troubles early on in the relationship with America meant that immigrants coming to America were doing so independent of the government. In comparison, Japan's involvement with America was strictly official from the start, when the only Japanese nationals in America were those 
sent with the approval of the Tokugawa government. The relationship between America and Japan was initially only official; as time went on, the cultural connection between Japan and America began to grow. Meanwhile, the official relationship remained, if not strong, at least consistent. Though the relationship with China was firmly established in the cultural realm, China's internal strife had made official relations difficult. Due to this gap, as evidenced by Portland, the relationship between China and America was dependent upon the relationship with Japan by the 1930s. For example, it was only when Japanese actions became reprehensible in the late 1930s that Portland fully supported China, and even then only reluctantly.

This paradigm extends to the post-war period. Both the U.S.S.R. and America aimed to fill the power vacuum created by Japan's defeat. For the Soviets, this meant giving more assistance to the Chinese Communist Party. For America, Japanese propaganda had made it very clear in the 1930s what a valuable ally Japan was. The rise and fall of militarism in Japan did not change the fact that Japan was indeed ideally suited to monitor and police the communist threat in East Asia. The improvements made in Japan during the "catching-up" phase were still there, and the Western-friendly businesses uniquely configured to exploit the Asian market still remained after the war. Almost all of the promises of opportunity from Japanese propaganda still remained, and America capitalized.

It has often been remarked how amazing it is that the relationship between America and Japan recovered so quickly after such a long and brutal war. While it is 
tempting to explain this reconciliation as a consequence of Japan's strategic value to America, when seen in the larger context of the relationship between the two countries, it is evident that the partnership between America and Japan was about more than strategy. The mutual respect gained around the turn of the twentieth century and the purposeful fostering of community on behalf of Japan created a truly lasting partnership that even war could not destroy.

What this study has revealed to me is that, when discussing public opinion, assumptions can be dangerous. Assuming that all areas of a country think like the majority can obscure the truth hidden in the complexities. Assuming that an eventual enemy's propaganda was never successful can oversimplify the evolution of public opinion. On the other hand, assuming uninterrupted support of an eventual ally can disguise the difficulties in the relationship. The opinion in Portland on this matter was different than the general American public opinion because of its history and connections with China and Japan. While the relationship between America and the Far East was diplomatic and economic, not much of a cultural relationship existed on the whole - at least not compared to Europe. However, the longer exposure to the Far East in Portland led to a more established cultural relationship between the two. While most of the country ignored the Far East to fret about the situation in Europe and how to solve it, the discussion in Portland reveals that the Far East drew just as much, if not more, attention than Europe. 


\section{Bibliography}

\section{Primary Sources:}

\section{Books, Journal Articles, and Official Works}

“1923 Alien Exclusion Law," accessed November 29, 2014, http://www.ccrh.org/comm/slough/primary/general.htm.

Hallett Abend \& Anthony J. Billingham, Can China Survive? (New York: Ives Washburn, Inc., 1936).

Hallett Abend, Tortured China (New York: Ives Washburn, 1930).

"America's Share in Japan's War Guilt." American Committee for Non-participation in Japanese Aggression, (New York, 1938).

"Appeal by the Chinese Government, Report of the Commission of Enquiry" (1932); Page 130, accessed March 7, 2015, http://www.wdl.org/en/item/11601/.

George Baidukov, Over the North Pole (New York: Harcourt, Brace and Co, 1938).

George H. Blakeslee, "The Japanese Monroe Doctrine," Foreign Affairs Vol. 11, No. 4 (1933).

Elizabeth Boody, “Manchoukuo, The Key to Japan's Foreign Exchange Problem," Far Eastern Survey Vol. 6, No. 10 (1937).

"Japan's Invasion Engulfs China in Horror and Sorrow," The China Information Committee, Hankow, China: 1937. 26. Found in Williston Papers.

Carl Crow, Japan and America, A Contrast (New York: Robert M. McBride \& Co., 1916).

W.L. Holland and Kate L. Mitchell, eds. Problems of the Pacific, 1936 (Chicago: University of Chicago Press, 1936).

Japan Pacific Association, What's it All About? Japan-China Pictorial Primer No. 1 (Tokyo: Japan Pacific Association, 1937).

"Japan's case in the Sino-Japanese dispute as presented before the Special session of the Assembly of the League of Nations," Accessed March 5, 2015, https://archive.org/details/japanscaseinsino00leag. 
The Japanese Foreign Office, Aggression at Shanghai (Seattle: Seattle Japanese Chamber of Commerce, 1937). Japanese Chamber of Commerce of New York. Manchukuo; the founding of the new state in Manchuria (New York: Japanese Chamber of Commerce, 1933).

K. K. Kawakami, Manchoukuo: Child of Conflict (New York: Macmillan Co, 1933).

Henry W. Kinney, Modern Manchuria and the South Manchuria Railway Company (Tokyo: The Japan Advertiser Press, 1928).

Gaku Matsumoto, The Cultural League of Nations; proposition (Tokyo: Nippon Bunka Renmei, 1936).

The Manchurian Question; Japan's Case in the Sino-Japanese Dispute as Presented Before the League of Nations, address given by Yosuke Matsuoka, Delegation to the League of Nations, December 8, 1932. Printed in report labeled the same.

Harry McNeill and West Meets East Committee, The Truth about Communism in China (New York: West Meets East Committee, 1939).

Frederick A. McKenzie, The Unveiled East (New York: E.P. Dutton \& Co., 1907).

Chih Meng, China Speaks (New York: The MacMillan Co., 1932).

Franz Michael, "The Significance of Puppet Governments," Pacific Affairs Vol. 12, No. 4 (1939).

Minami Manshū Tetsudō Kabushiki Kaisha, Manchuria, land of opportunities (New York: South Manchuria railway, 1922).

F. Mödlhammer, Moscow's Hand in The Far East (Tokyo: Nippon Dempo Tsushinsha, 1938).

H. B. Montgomery, The Empire of the East (Chicago: A.C. McClurg \& Co., 1909).

National Lawyers Guild, Oregon Chapter. Civil Liberties Committee, Report of the Civil Liberties Committee (Portland: ACLU, 1938).

The puppet state of "Manchukuo" (Shanghai: China United Press, 1935).

George Bronson Rea. The Case for Manchoukuo (New York: Appleton-Century, 1935).

Lindsay Russell, ed. America to Japan (New York: The Knickerbocker Press, 1915). 
Hirosi Saito. "My Impressions in the Far East and Japanese-American Relations." Delivered at the Academy of Political and Social Science, Philadelphia, PA. November 23, 1934. Found in Williston Papers.

James A. B. Scherer, Manchukuo A Bird's-Eye View (Tokyo: Hokuseido Press, 1933).

"The Second America-Japan Student Conference, 1935," The Second America-Japan Student Conference Papers, Portland OR, Reed College Libraries, Archives Department.

"Stimson Doctrine, 1931." Stimson Doctrine, 1931 (January 2009): 72. Academic Search Premier, EBSCOhost (accessed May 10, 2014).

Anna Louise Strong, China's Millions (New York: Knight Publishing Co., 1935).

Transcript appearing in Department of Western Languages, In These Times (Peiping: Yenching University, 1936).

Transcript of speech given in Roseburg during 1934 (no other information available), Box 7 of Floyd C. and Benjamin F. Ramp Papers, 1874-1973. University of Oregon Libraries, Archives Department.

Eleanore Tupper \& George E. McReynolds, Japan in American Public Opinion (New York: The MacMillan Co., 1937).

Sydney Tyler, Great Battles of History Vol. V, The Japan-Russia War (Philadelphia, P.W. Ziegler Co., 1905).

Harold M. Vinacke, A History of the Far East in Modern Times (New York: F. S. Crofts \& Co., 1928).

Ching-Chun Wang, Whither Manchuria? (London: Fish \& Cook, 1932).

"Whither Manchuria?" Ching-Chun Wang. The World To-day (London: February, 1932), 13. Found in Williston Papers.

B. L. Putnam Weale, The Truth about China and Japan (New York: Dodd, Mead \& Co., 1919).

Trumbull White, The War in the East (Philadelphia: J. H. Moore Company, 1895).

H. G. W. Woodhead. A Visit to Manchukuo (Shanghai, China: Mercury Press, 1932). 
Quincy Wright, "The Stimson Note of January 7, 1932," The American Journal of International Law, Vol. 26, No.2 (1932).

\section{Newspapers, Newsletters, etc.}

4/22/41 Meeting Minutes, Pgs 4-5. Joseph B. McAllister Papers, 1936-1942, University of Oregon Libraries, Archives Department.

“America and Japan," The Portland City Club Bulletin 13, no .36 (1933).

"Another Japan Line Agents of The Toyo Kisen Kaisha Will Visit Portland," The Oregonian, July 24, 1896.

Beaux Art Productions. "Manchukuo: the Newborn Empire." The Internet Archive, 13:09, Accessed March 7, 2015. https://archive.org/details/manchukuo_the_newborn_empire.

Hamilton Bulter, "American Delusions About China," The American Mercury, January 1933, p. 105. Accessed May 1, 2015. http://www.unz.org/Pub/AmMercury-1933jan00103.

"The Case of Miss Bryant," The Oregonian, March 28, 1919, 11.

"China's Future Promising Says Hocking," The Portland City Club Bulletin 14, no. 21 (1933).

"The Chinese," The Morning Oregonian, June 21, 1864.

"Chinese Consul Condemns Japanese Aggression," The Portland City Club Bulletin 18, no. 30 (1937).

Upton Close, “Banzai, Manchukuo!” The Saturday Evening Post, February 25, 1933.

“Commerce with Japan," The Oregonian, October 10, 1912.

"Communism in China Gets Light Turned on It" The Sunday Oregonian, December 1, 1935.

“Defense Against Revolution" The Oregonian, January 19, 1931.

"Development of Peace Pacts Declared Need in Pacific," Portland City Club Bulletin, 16, no. 12 (1935).

"Drive on Bandits Fails" The Oregonian, June 27, 1932. 
E. Guy Talbott to Frederick J. Libby, September 10, 1935, NCPW Papers.

"Finnish Cases to Open" The Oregonian, June 9, 1931.

"Five Alleged Reds Bagged in Portland," The Oregonian, February 9, 1919.

“Greetings to Mr. Matsuoka," The Oregonian, April 7, 1933.

David W. Hazen, "Envoy of Japan Welcomed Here," The Oregonian, May 4, 1939.

David W. Hazen, “Matsuoka, Japan's Noted Statesman, Once Peddled Coffee in

Portland," The Oregonian, March 26, 1933.

"Henry, The Incubated Emperor" The Oregonian, January 13, 1934.

"Heroes of Flight Soar to Oakland" The Oregonian, June 22, 1937.

“High Officials Genuine Hosts," The Oregonian, September 25, 1936.

"A Hotbed of Treason" The Oregonian, November 13, 1917.

Hu Shih, "The Issues Behind the Far Eastern Conflict" (Address, Foreign Policy Association, New York, November 13, 1937).

Kiyo Sue Inui, LL.D. "The United States and Japan in Asia" (Address, Commonwealth Club of California, San Francisco, CA, April 26, 1940).

J. J. Handsaker to NCPW, July 19, 1935, National Council for the Prevention of War Papers, Swarthmore Peace Archives, Swarthmore College, Box 125, mf reel 41:112.

“Report Letter \#3," J. J. Handsaker to NCPW, September 19, 1935, NCPW Papers.

“Japan Still Defiant and Why." The Oregonian, August 27, 1932.

"Japanese Cadets Will be Welcomed," The Oregonian, July 17, 1934.

“Japanese Praise Oregon Scenery," The Oregonian, August 1, 1935.

"Japanese Consul Reviews Far-Eastern Conflict," The Portland City Club Bulletin 18, no. 29 (1937).

"Japanese Industry Wants Peace Says Dr. Fridell," The Portland City Club Bulletin 14, no. 31 (1933). 
"John Reed is Arrested," The Oregonian, March 18, 1920, 2.

“John Reed, of Portland, goes to Russian Front," The Oregonain, April 4, 1915, 2.

“Let's Stay American" The Sunday Oregonian, March 15, 1936.

"Lumber Going out. Cargo Purchased for Japanese Steamer Revives Interest," The Oregonian, October 17, 1914.

"Man \& Wife of the Year." Time 31, no. 1(January 3, 1938): 14. Academic Search Premier, EBSCOhost, accessed May 11, 2014.

"Manchuria, discussed by Roy H. Agaki, T.Z. Koo, Joseph P. Chamberlain, January 23, 1932." Pamphlet published by the Foreign Policy Association. Found in the Frank Williston Papers, University of Puget Sound Archives, Collins Memorial Library.

“Matsuoka Honors Boyhood Friend," The Sunday Oregonian, April 10, 1933.

"Matsuoka Wary of Naval Splurge," The Oregonian, April 8, 1933.

Pat McGrady, "Far East Listens to America's Word," The Oregonian, March 1, 1933.

"Morals of Japanese Army" The Oregonian, March 12, 1938.

“Northwest China overrun by Reds" The Sunday Oregonian, April 19, 1931.

"Old Parties Are Grilled by Debs, Large Audience Hears Socialist Nominee," The Oregonian, September 15, 1908.

The Oregonian, June 19, 1937.

The Oregonian, September 18, 1933.

"The Overture To Russia" The Oregonian, October 22, 1933.

"Peace and Order in Asia Declared Vital," Portland City Club Bulletin, 17, no. 15 (1936). Portland City Club Bulletin 15, no. 30 (1934).

"Portland To Send Trucks To Orient Northwest Auto Company Contract With Japanese. \$150,000 Total Involved," The Oregonian, December 14, 1919.

"Russia Declared Opposed to War" The Oregonian, March 17, 1936. 
"Short Life of John Reed Filled with Startling Incidents and Adventures," The Oregonian, November 7, 1920, Section 5, 1.

Special to THE NEW YORK TIMES. "SEES REAL MENACE IN JAPAN'S POLICY." New York Times (1923-Current File), May 17, 1935. http://search.proquest.com/docview/101524362 ?accountid=13265.

"Strengthen China and Remove Manchurian Difficulties Says Speaker," The Portland City Club Bulletin 13, no. 46 (1933).

"The Three Arrive From Moscow" The Oregonian, June 22, 1937.

"The Toveri Editors Case" The Oregonian, May 8, 1919, 10.

"Trade Commissioner From Tokyo Speaks," The Portland City Club Bulletin 15, no. 10 (1934).

Fred W. Vincent, "Why Japan Rattles the Sabre," The Sunday Oregonian, June 3, 1934, Magazine Section.

\section{Secondary Sources:}

Masaharu Ano, "Yosuke Matsuoka: The Far-Western Roots of a World-Political Vision," Oregon Historical Quarterly 98 (1997).

Charles Beard, President Roosevelt and the Coming of War (New Haven: Yale University Press, 1948)

Phil Billingsley, Bandits in Republican China (Stanford: Stanford University Press, 1988).

"A Brief History of Newspaper Publishing in Oregon," accessed May 31, 2014, http://library.uoregon.edu/govdocs/indexing/newspaperhistory.html.

Hurst III, G. Cameron. "Death, honor, and loyalty: The bushido ideal." Philosophy East \& West 40, no. 4 (October 1990).

"Exports, by country of destination: 1790-2001" in Historical Statistics of the United States, Millennial Edition On Line, edited by Susan B. Carter, Scott S. Gartner, et al. (Cambridge University Press, 2006).

Chinese Consolidated Benevolent Association, Dreams of the West; $A$ history of the Chinese in Oregon 1850-1950 (Ooligan Press, Portland, 2007). 
Campbell Gibson and Kay Jung, "Historical Census Statistics On Population Totals By Race, 1790 to 1990, and By Hispanic Origin, 1970 to 1990, For Large Cities And Other Urban Places In The United States" (Paper prepared for the U.S. Census Bureau, February 2005), 93, accessed November 12, 2015, https://www.census.gov/population/www/documentation/twps0076/twps0076.pdf.

"All the World a Melting Pot?" by Neil Harris in Akira Iriye et al. Mutual Images : Essays in American-Japanese Relations (Cambridge: Harvard University Press, 1975).

George C. Herring, From Colony to Superpower: U.S. Foreign Relations since 1776 (New York: Oxford University Press, 2008).

"Historical Census Browser," University of Virginia Library, 2004, accessed November 20, 2014, http://mapserver.lib.virginia.edu/php/.

"Historical Information," accessed June 3, 2014, http://www.swarthmore.edu/library/peace/DG001025/dg023NCPW/Historicallntroduction.htm.

Nelson Chia-Chi Ho, Portland's Chinatown: The History of an Urban Ethnic District (Portland, Bureau of Planning, City of Portland, 1978).

Eric Homberger, John Reed (Manchester: Manchester University Press, 1990).

Paul George Hummasti, Finnish Radicals in Astoria, Oregon, 1904-1940: A Study in Immigrant Socialism (PhD Diss., University of Oregon, 1975).

Akira Iriye, "Japanese Aggression and China's International Position 1931-1949," in The Cambridge History of China Volume 13: Republican China 1912-1949, Part 2, ed. John K. Fairbank et al. (Chicago, University of Chicago Press, 1986).

Akira Iriye, "Japan as a Competitor, 1895-1917," in Mutual Images, Essays in AmericanJapanese Relations, ed. Akira Iriye (Cambridge: Harvard University Press, 1975).

"Japan Oregon Relations," accessed November 29, 2014, http://www.portland.us.embjapan.go.jp/tips/Japan-Oregon\%20Relations\%EF\%BC\%882014\%2006\%EF\%BC\%89.pdf.

Jeffrey A. Johnson, "They Are All Red Out Here": Socialist Politics in the Pacific Northwest, 1895-1925 (Norman: University of Oklahoma Press, 2008).

Philip Kuhn, Chinese among Others : Emigration in Modern times (State and Society in East Asia, Lanham: Rowman \& Littlefield Publishers, 2008). 
Daniel J. Meissner, "Theodore B. Wilcox: Captain of Industry and Magnate of the China Flour Trade, 1884-1918," Oregon Historical Quarterly 104 (2003).

Salvatore Prisco, III, “John Barrett and Oregon Commercial Expansion 1889-1898," Oregon Historical Quarterly 71 (1970).

Roth, Mitchel P. Encyclopedia of War Journalism - 1807-2015 -3rd Ed. (Grey House Publishing, 2015).

Carlos A. Schwantes, Radical Heritage (Seattle: University of Washington Press, 1979).

Charles B. Wordell, Japan's Image in America, Popular Writing about Japan, 1800-1941 (Kyoto: Yamaguchi Publishing House, 1998).

Yamamuro Shin'ichi, and Joshua A. Fogel, Manchuria under Japanese Dominion (Philadelphia: University of Pennsylvania Press, 2006).

Barbara Yasui, "The Nikkei in Oregon, 1834-1940," Oregon Historical Quarterly 76 (1975). Zhang Yongjin, China in the International System,1918-20: The middle Kingdom at the Periphery (London: St. Antony's, 1991). 